\title{
THE QUALIFTED DEFERRED COMPENSATION PLAN OF AN ACQUIRED CORPORATION: BASIC CONSIDERATIONS IN A CORPORATE ACQUISTTION
}

\author{
Patricta Ann Metzer $\dagger$
}

Bolden Corporation is approached by Dynamic Enterprise, Inc., a corporation which in fact, if not ostensibly, wishes to acquire Bolden by purchasing either its assets or its stock in return for stock or cash, in either a tax-free or a taxable reorganization. The proposed transaction suggests basic areas of consideration for both prospective parties: the value of Bolden's assets; the value of the consideration; the form of the acquisition; the terms of payment; and the liabilities to be assumed by the acquiring corporation. Each basic area of consideration relates generally to the business activities of the selling corporation. ${ }^{1}$ The seller, however, has a qualified deferred compensation plan, approved by the Internal Revenue Service under section 401 of the Internal Revenue Code, ${ }^{2}$ with or without a trust exempt from taxation under section $501 .^{3}$ Frequently, the disposition of the seller's qualified deferred compensation plan is overlooked until the last moment, an unwise and perhaps unconscious decision, engendered by the very real time pressures which tend to surround all corporate acquisitions.

Whether conscious or unconscious, such an oversight may be critical, for the seller's qualified deferred compensation plan can, and perhaps should, affect not only the price of the acquisition, ${ }^{4}$ but also

$\dagger$ B.A. 1963, LI.B. 1966, University of Pennsylvania. Member, Massachusetts Bar.

1 Throughout this paper, the terms "selling corporation," "seller," and "acquired corporation" will be used interchangeably, although in the case of a stock acquisition, the terms "selling corporation" and "seller" are not accurate-the "sellers" in fact being shareholders.

2 INT. Rev. CoDe of 1954, §401. A qualified deferred compensation plan is of special tax benefit to the employees covered as well as to the employer corporation. The corporation receives a current income tax deduction for plan contributions, within the limits set forth in id., $\$ 404$, and covered employees are not taxed on such contributions until plan assets are actually distributed to them, generally upon their termination of employment. $I d, \S 402$. In addition, all plan income accumulates on a tax-free basis, until actually distributed to covered employees. Id., $\$ 501(\mathrm{a})$.

${ }^{3} I d$., $\$ 501$ (a). Technically, $i d$., $\S 401$ deals with qualified deferred compensation "trusts," which are tax exempt under $\$ 501$ (a) of the Code. However, a corporation may apparently establish a qualified deferred compensation plan without a trust. This is likely to occur in the case of a union plan, where a joint union-employer pension committee is established to administer the plan and where all plan contributions are transmitted directly to an insurer.

* See generally Cox, The Effect of Corporate Acquisitions on Pension and ProfitSharing Plans, in TAXation of DEFERrEd EMPLOYeE aNd Executrve CoMpensation 413 (H. Sellin ed. 1960) [hereinafter cited as Cox, Corporate Acquisitions] ; B. Fox \& 
the method of reorganization ${ }^{5}$ and the nature of the warranties given by both the acquired and acquiring corporations. ${ }^{b}$ Last minute review of the seller's plan means, of course, that the plan can have little or no effect on these aspects of the acquisition, unless the initial or final closing date is postponed.

It is also significant that plan amendments ${ }^{7}$ and government approval of certain proposed transactions affecting the seller's qualified plan ${ }^{8}$ may be required prior to the actual closing date. If the government will permit retroactive amendment of the seller's plan following the closing, the amendment problem may be solved, although reliance on a retroactive amendment may still be subject to risk. ${ }^{9}$ The advance ap-

E. Fox, Corporate AcQuisimions ANd Mergers $\$ 5.06[2]$ (1968); Robbins, Effect of Corporate Reorganizations on Pension and Profit Sharing Plans, N.Y.U. 17TH INST. ON FED. TAX. 951, 952 (1959) ; Rustigan, Effect of Business Reorganization on Pension and Profit Sharing Plans, 18 TAX ExEC. 279, 280 (1966). For a list of factors that affect price see Reisner, Pension and Profit-Sharing Problems, 40 TAXes 157, 158 (1962); Taft, The Tax Effect of Corporate Reorganizations on Pension Plans, 41 Notre Dante Law. 471, 486 (1966).

5 Robbins, supra note 4, at 952-53.

- See, e.g., Qualified Retirentent Plans-Capital Gain Distributions, TAx MANagement MenroRandum No. 68-09, at 9 (Apr. 22, 1968); Weithorn \& Elder, Buyer's and Seller's Points in Sale of Corporate Business: An Outline-Checklist, N.Y.U. 21st INST. ON FED. TAX. 1065, 1081 (1963). See generally Houston, How Warranties can be used to control tax consequences in corporate acquisitions, $28 \mathrm{~J}$. TAXation 22 (1968). For example, in the case of a pension plan, the buyer might require a representation that there are no unfunded past service liabilities, other than those specifically noted in the representation.

${ }^{7}$ See B. Fox \& E. Fox, supra note 4, at $\$ 5.06[2]$; Cox, Amendments and Terminations of Pension and Profit-Sharing Plans, N.Y.U. 14TH INST. ON FED. TAX. 1181, 1215-16 (1956) [hereinafter cited as Cox, Amendments]; Duncan, Pension Planning for Merged or Related Companies, N.Y.U. 15TH INST. ON FED. TAX. 1195, 1198-99 (1957) ; Harrison, Acquisitions and qualified pension plans; studies on corporate take-overs, Cases I and III, $15 \mathrm{~J}$. TAXATION 36, 36-37 (1961); Robbins, supra note 4, at 953-54. An amendment may be required if the acquiring corporation wishes to continue the acquired corporation's deferred compensation plan; without an amendment the plan may by its terms terminate as of the closing. $\mathrm{Or}$, if the acquiring corporation does not wish to continue the acquired corporation's plan, an amendment may be required in connection with the manner of distribution of plan benefits in order to prevent discrimination, and, perhaps, to reduce the tax impact upon employees.

8 For example, if the plan is to be terminated, government approval should be obtained, so that after termination the government cannot assert that due to the termination, the plan was never a qualified plan, or in the alternative, that the plan was nonqualified, at least during the final year of its operation.

9 Treas. Reg. $\$ 1.401-5$ (1956) provides that an employer may retroactively amend its pension, profit-sharing, or other deferred compensation plan within $2 \mathrm{r} / 2$ months after the close of its taxable year, in order to satisfy the qualification requirements of the Code. The regulation by its terms relates only to newly established plans and to the problem of discrimination, but might in modified form be applied to plans that have been in effect for more than one taxable year. For example, in the case of tax-free mergers and asset acquisitions, the taxable year of the acquired corporation will generally end on the closing date, see INT. REv. CODE OF 1954, $\$ 381$ (b), so that presumably the acquired corporation (in the case of an asset acquisition) or the surviving corporation (in the case of a merger) will have $2 \mathrm{r} / 2$ months after such date in which to amend retroactively the acquired corporation's qualified plan. However, even if the regulation is stretched to apply to older plans, it would appear that only amendments relating to plan qualification will be allowed, so that if the plan automatically terminates as of the closing, retroactive reactivation would appear to be impossible (even if otherwise possible under state law).

In the case of tax-free mergers and asset acquisitions, Treas. Reg. $\$ 1.381$ (c) (11)1 (b) (2) (1961) also permits the acquiring corporation to amend retroactively the 
proval problem, however, remains. Last minute consideration of the seller's deferred compensation plan generally excludes the possibility of preclosing government approval of any proposed amendment or plan transaction. ${ }^{10}$

There would appear to be only two basic deferred compensation questions that the acquiring corporation should consider upon review of the seller's qualified plan, and these questions are significant not only from the buyer's point of view, but also from the seller's. First, should the seller's plan be continued or terminated after the acquisition? Second, if plan continuation is deemed to be the better alternative, in what manner should the seller's plan be continued-as an inactive or separate, active plan, or as part of the buyer's existing deferred compensation program?

In answering these questions, both the buyer and the seller may determine what effect, if any, the seller's plan should have on the price of the acquisition, the method of reorganization, and the nature of the warranties to be given by both parties. Both parties may, in addition, determine what, if any, preclosing amendments and government authorizations are required. Because of the substantial impact that the answers to these two basic questions can have on corporate acquisitions, each question must be examined from the viewpoint of both the buying and the selling corporation.

\section{Should the Selier's Plan Be Terminated?-The Buyer's PoINT OF VIEW}

\section{A. General Considerations}

Many tax and tax-oriented questions must be considered by the buyer in determining whether or not to terminate the seller's qualified deferred compensation plan. At the same time, however, certain policy and people-oriented considerations cannot be overlooked.

For example, if the acquiring corporation does not have a plan for its own employees, it would be unwise to continue the acquired

acquired corporation's qualified plan, subject to the provisions of Treas. Reg. $\$ 1.401-5$ (1956), but the same restrictions would presumably apply, making such amendment impossible if the acquiring corporation failed to adopt the acquired corporation's plan at the time of the closing.

10 For a general discussion of the need for early consideration of the seller's qualified deferred compensation plan and the relevant factors see B. Fox \& E. Fox, supra note 4, at $\$ 5.06[2]$; Reisner, supra note 4, at 158-60; Seligman, Jr., Termination, Suspension and Conversion of Qualified Pension and Profit-Sharing Retirement Plans, U. So. Cal. 1961 TaX INST. 353, 354; Wood, Pension Plans and Business Combinations-Part I, 3 MERGERs \& AcQ's 20, 21 (Jan.-Feb., 1968) [hereinafter cited as Wood, Pension Plans-Part I]. See also Dierks v. Thompson, Civil No. 3238 (D.R.I., Jan. 21, 1969), rev'd, Civil No. 7293 (1st Cir. Aug. 8, 1969) (former employees of a corporate division established in trial court a partial termination of their former employer's qualified profit-sharing plan caused by sale of the division's assets, but reversed on appeal). 
corporation's plan for only transferred employees, unless the acquired corporation is retained as a subsidiary (or perhaps a division) of the buyer. If, on the other hand, the buyer already has a qualified plan, it may wish to maintain only one plan for its employees and those of any subsidiary corporation, in which case plan termination would be the better alternative. ${ }^{11}$ Or, if no employees of the selling corporation become employees of the buyer, plan termination might be the only feasible approach.

Conversely, it may be desirable for purposes of morale to have a separate plan for transferred employees, where the selling corporation becomes a subsidiary or a division of the buyer. Or, there may be no need to terminate the seller's plan if it is in most respects identical to the buyer's existing program. ${ }^{12}$

\section{B. Carryovers}

The tax considerations that face the acquiring corporation are more complex than the evaluation of policy, and perhaps the most complex tax consideration is that of the carryover.

Section 404(a) (1) (D) of the Code ${ }^{13}$ provides with regard to pension plans that any plan contributions not deductible in a particular taxable year under the deduction limitations of the Code can be carried over and deducted in succeeding taxable years, subject, however, to the deduction limitations spelled out in subsections (A), (B), and (C) of section $404(\mathrm{a})(1) .{ }^{14}$ Subsection (C) allows a taxpayer corporation to deduct in any one taxable year the normal annual cost of its pension plan and up to ten per cent of the total amount required to fund past service credits accrued by plan participants. ${ }^{15}$ Alternatively,

11 If a subsidiary corporation adopts its parent's qualified profit-sharing plan and if both corporations represent an affiliated group as defined in INT. REv. CoDE of $1954, \S 1504$, the benefits of INT. REv. CoDE of 1954, \$404(a) (3) (B) will be available. Section $404(\mathrm{a})(3)(\mathrm{B})$ provides generally that if any member of an affiliated group is unable to make a contribution to its qualified profit-sharing plan due to inadequate current or accumulated earnings or profits, the other members of the group may make the contribution out of their current or accumulated earnings or profits, on a tax deductible basis. See Rev. Rul. 67-214, 1967-2 Cuar. Bull. 160; Duncan, supra note 7, at 1206-07; Gordon, Discrimination Problems in the Drafting and in the Operation of Pension and Profit-Sharing Plans, N.Y.U. 14TH INST. ON FED. TAX. 1153, 1180 (1956); Iurie, Plastic Contributions For Pensions and Profit-Sharing, 67 YALE I.J. 1003, 1014 (1958) [hereinafter cited as Lurie, Plastic Contributions].

12 On the general subject of policy considerations see B. Fox \& E. Fox, supra note 4, at $\$ \$ 5.06[2]-[4]$; Duncan, supra note 7, at 1196, 1200; Taft, supra note 4, at 472 .

13 INT. Rev. CODE OF 1954, §404(a) (1) (D).

14 Id., $\$$ 404(a) (1) (A), (B) \& (C).

15 Specifically, $\$ 404$ (a) (1) (C) provides that the employer may deduct:

[A]n amount equal to the normal cost of the plan, as determined under regulations prescribed by the Secretary or his delegate, plus, if past service or other supplementary pension or annuity credits are provided by the plan, an amount not in excess of 10 percent of the cost which would be required to completely fund or purchase such pension or annuity credits as of the date 
subsections (A) and (B) together allow a taxpayer corporation to deduct on an annual basis the one year cost of current and past service credits accrued by plan participants when the total cost of such credits for each participant is spread evenly over the participant's remaining future service. ${ }^{16}$

In the case of profit-sharing plans, the Code incorporates two separate carryover provisions. Section 404 (a) (3) (A) ${ }^{17}$ provides that any plan contributions not deductible in a particular taxable year under the applicable limitations can be carried over and deducted in succeeding taxable years, subject, however, to the requirement that no carryover and current deductions can together exceed fifteen per cent of the total compensation of participating employees for the corporate taxable year

when they are included in the plan, as determined under regulations prescribed by the Secretary or his delegate, except that in no case shall a deduction be allowed for any amount (other than the normal cost) paid in after such pension or annuity credits are completely funded or purchased.

See Treas. Reg. $\$ \$ 1.404$ (a) -6(a) (2) \& (3), T.D. 6534, 1961-1 CuM. BuL. 145; Rev. Rul. 70-30, 1970 INT. Rev. BuLr. No. 3, at 10.

16 Specifically, $\S \$ 404$ (a) (1) (A) \& (B) provide that the employer may deduct:

(A) an amount not in excess of 5 percent of the compensation otherwise paid or accrued during the taxable year to all the employees under the trust, but such amount may be reduced for future years if found by the Secretary or his delegate upon periodical examinations at not less than 5-year intervals to be more than the amount reasonably necessary to provide the remaining unfunded cost of past and current service credits of all employees under the plan, plus

(B) any excess over the amount allowable under subparagraph (A) necessary to provide with respect to all of the employees under the trust the remaining unfunded cost of their past and current service credits distributed as a level amount, or a level percentage of compensation, over the remaining future service of each such employee, as determined under regulations prescribed by the Secretary or his delegate, but if such remaining unfunded cost with respect to any 3 individuals is more than 50 percent of such remaining unfunded cost, the amount of such unfunded cost attributable to such individuals shall be distributed over a period of at least 5 taxable years. . . .

See Treas. Reg. $\$ \$ 1.404(a)-5$ (c) \& (d) (1956).

The deductions available under subsections (A) and (B) of $\S 404$ (a) (1) are in no way affected by the limitation under $\$ 404(\mathrm{a})(1)(\mathrm{C})$, although at one time the government tried to impose a further $10 \%$ limitation under subsections (A) and (B). The government's position was rejected by the Tax Court in Saalfield Publishing Co., 11 T.C. 756 (1948), not acquiesced in, 1949-1 CUM. BULL. 6, acquiesced in, 1952-2 Cum. Bull. 3, and by at least one federal district court, Philadelphia Suburban Transp. Co. v. Smith, 105 F. Supp. 650 (E.D. Pa. 1952). Finally, in 1956, the regulations were amended to eliminate the $10 \%$ requirement under $\$ \$ 23$ (p) (1) (A) (i) \& (ii) of the 1939 Code, predecessor of $\$ \$ 404$ (a) (1) (A) \& (B) of the 1954 Code. Treas. Reg. 118, \$39.23(p)-6(e), T.D. 6189, 1956-2 CuM. BuLL. 972, as anended. Treas. Reg. \$1.404(a)-5(d) (1956); see Rev. Rul. 56-530, 1956-2 CuM. ButL. 974. See also Rev. Rul. 57-89, 1957-1 Cur. Buld. 169; Rev. Rul. 67-427, 1967-2 CuM. BULI. 156, in which the Commissioner ruled that under a split-funded pension plan (side fund plus ordinary life policies), contributions to the side fund could not be deducted under $\$ 404$ (a) (1) (C), when life insurance premiums were deducted under $\$ \$ 404$ (a) (1) (A) \& (B). Where the employer has a pension plan with two types of funding vehicles-side fund plus ordinary life policies for benefits in excess of $\$ 150$ a month, and group life insurance plus a deposit administration contract for benefits up to $\$ 150$ a month-query whether the employer may claim a deduction under $\$ 404$ (a) (1) (C) for the cost of benefits up to $\$ 150$ a month and under $\$ \$ 404$ (a) (1) (A) \& B for the cost of benefits over $\$ 150 \mathrm{a}$ month.

17 INT. Rev. Code of 1954, §404(a) (3) (A). 
under review. ${ }^{18}$ Section 404 (a)(3)(A) also provides that if a taxpayer corporation does not contribute the maximum deductible amount to its qualified profit-sharing plan during a particular taxable year, the unused amount may be deducted in the future year of contribution, in addition to the maximum amount then deductible under the fifteen per cent limitation described above, ${ }^{19}$ subject, however, to the requirement that any unused amount deductible during a subsequent taxable year cannot exceed fifteen per cent of the total compensation paid and accrued to or on behalf of participating employees during that taxable year. ${ }^{20}$

\section{1. " $\mathrm{A}$ " and "C" Reorganizations}

In certain tax-free reorganizations, the carryovers available to an acquired corporation are made available to the acquiring corporation by statutory provision. Section 381 (c) (11) ${ }^{21}$ provides that for purposes of determining the amounts deductible with respect to pension and profit-sharing plans under section 404 , the acquiring corporation must step into the shoes of "the distributor or transferor corporation after the date of distribution or transfer . . .."22 Section 381(c) (11) ap-

18 See Treas. Reg. $\$ \$ 1.404$ (a) -9 (c), (d), (e), \& (g), T.D. 6534, 1961-1 CuM. Butc. 145; Lurie, Plastic Contributions 1013-14.

${ }^{19}$ See Treas. Reg. $\$ \$ 1.404$ (a) -9(c), (d), (e), \& (g), T.D. 6534, 1961-1 Cun. Bull. 145; Lurie, Plastic Contributions 1012-13. The carryover contribution is available, notwithstanding the fact that during the taxable year with respect to which the unused contribution carryover arose, the employer may have contributed the amount required (or less than the amount required) under the fixed contribution formula spelled out in the plan agreement. Similarly, the deduction carryover is available, notwithstanding the fact that during the taxable year with respect to which the carryover arose, by reason of a contribution in excess of the then deductible amount, the employer may have made a contribution in excess of the amount required under a fixed contribution formula set forth in the plan. The government had taken a different position under the 1939 Code, I.T. 4055, 1951-2 CuM. Bull. 30, modified, Rev. Rul. 56-366, 1956-2 Cun. Bull. 976; see McClintock-Trunkey Co., 19 T.C. 297 (1952), rev'd, 217 F.2d 329 (9th Cir. 1954); Wooster Rubber Co., 14 T.C. 1192 (1950), rev'd on other grounds, 189 F.2d 878 (6th Cir. 1951) ; Progressive Welder Co., 12 CCH TAX C. MEAs. 1012 (1953), when applicable law called for a fixed contribution formula under qualified profit-sharing plans. I.T. 3661, 1944 CuM. Bul. 315, distinguished, PS No. 33, Sept. 20, 1944, declared obsolete, Rev. Rul. 67-467, 1967-2 CUMr. BuLl. 432. The fixed contribution requirement was eliminated by T.D. 6189, 1956-2 Cunr. Bull. 972.

20 There is an additional carryover limitation, applicable when the employer has both a qualified pension and a qualified profit-sharing plan, under which at least one common employee is a beneficiary. INT. REv. CoDE OF 1954, \$ 404 (a) (7); see Parker Pen Co. v. O'Day, 234 F.2d 607 (7th Cir. 1956), aff'g 133 F. Supp. 67 (E.D. Wis. 1955); Treas. Reg. \$1.404(a)-13, T.D. 6534, 1961-1 Cum. BuLr. 145; Treas. Reg. \$1.381(c) (11)-1(h) (1961); Musto, Carryover problems of compensation plans in corporate reorganizations, $25 \mathrm{~J}$. TAXation 270, 271-72 (1966).

21 INT. Rev. CoDE of 1954, \$381(c) (11). "The purpose of the exemption provisions in the Code, governing transactions in corporate reorganizations, is to remove an impediment to a corporate readjustment and to prevent taxation of purely fictitious gains." Rev. Rul. 58-193, 1958-1 CUM. Bunt. 208, 209; see Goodman, How Reorganizations Affect Pensions and Profit-Sharing Plans, 38 'TAxes 155, 166 (1960) [hereinafter cited as Goodman, Reorganizations].

22 INT. Rev. CODE of 1954, \$381(c) (20) deals specifically with qualified pension plans. However, this subsection (added by Act of Jan. 28, 1956, 70 Stat. 7) applies only under special circumstances to a corporation which acquired the property of a wholly owned subsidiary in a liquidation covered under INT. REV. CODE OF 1939, 
plies specifically to tax-free statutory mergers and consolidations and to tax-free assets-for-voting-stock deals (" $A$ " and " $C$ " reorganizations ${ }^{23}$ ), although not to what, under a step transaction approach, represents a tax-free or taxable acquisition of assets for voting stock (i.e., a section 334(b) (2) liquidation). ${ }^{24}$

The advantages of section 381 (c) (11) will clearly be available to the acquiring corporation if it elects to continue the seller's qualified deferred compensation plan. Thus, if the acquisition involves an " $\mathrm{A}$ " or a " $\mathrm{C}$ " reorganization, and the selling corporation has unused deduction or contribution carryovers, the acquiring corporation will inherit these carryovers if it continues the seller's plan on a qualified basis. $^{25}$ This benefit will accrue to the buyer without an appropriate acquisition price adjustment, if the seller is not alert to the favorable transfer. On the other hand, discontinuance of the seller's plan will

\$112(b) (6). See Corporate Acquisitions-Employee Benefit Plans, TAx MANaGeMENT PORTFOLIO No. 92-2d, at A-13.

23 INT. REv. CODE of 1954, §\$ 368(a) (1) (A) \& (C).

24 See id., $\$ 334(\mathrm{~b})(2)$. Specifically, id. $\$ 381$ will apply:

[i]n the case of the acquisition of assets of a corporation by another corporation-

(1) in a distribution to such other corporation to which section 332 (relating to liquidation of subsidiaries) applies, except in a case in which the basis of the assets distributed is determined under section 334 (b) (2); or

(2) in a transfer to which section 361 (relating to nonrecognition of gain or loss to corporations) applies, but only if the transfer is in connection with a reorganization described in subparagraph (A), (C), (D) (but only if the requirements of stupparagraphs $(A)$ and $(B)$ of section $354(\mathrm{~b})$ (1) are met), or (F) of section 368(a) (1) . . .

\section{Id. $\S 381(\mathrm{a})$.}

INT. REv. CODE of 1954, \$368(a) (1) (A) deals with statutory mergers and consolidations, while subsection (C) of section 368(a) (1) deals with "the acquisition by one corporation, in exchange solely for all or a part of its voting stock (or in exchange solely for all or a part of the voting stock of a corporation which is in control of the acquiring corporation), of substantially all of the properties of another corporation. - . See generally TAX MANAGEMrent PoRTFoLto No. 92-2d, supra note 22, at A-4 A-5; Wood, Pension Plans-Part I 26-27. But cf. Rev. Rul. 67-274, 1967-2 CUM. BuLl. 141, where the government found a " $C$ " rather than a " $B$ ", reorganization under a step transaction analysis. It is unclear whether the ruling involved a $\$ 334(\mathrm{~b})(2)$ liquidation.

25 Treas. Reg. $\$ 1.381$ (c) (11)-1(d) (1961). There is, however, one caveat. INT. REv. CoDe of 1954, \$ 404(a) (6) provides that:

[A] taxpayer on the accrual basis shall be deemed to have made a payment on the last day of the year of accrual if the payment is on account of such taxable year and is made not later than the time prescribed by law for filing the return for such taxable year (including extensions thereof).

Thus, if the acquired corporation in an " $\mathrm{A}$ " or a " $\mathrm{C}$ " reorganization accrued a profitsharing contribution prior to the closing and the acquiring corporation made a carryover contribution to the acquired corporation's profit-sharing plan within $2 \mathrm{~T} / 2$ months after the closing (when presumably the acquired corporation's taxable year ended under INT. REv. CODE OF 1954, $\$ 381(\mathrm{~b})$ ), the deduction would be available to the acquired rather than the acquiring corporation, if not in excess of the accrued contribution. Treas. Reg. \$1.381(c) (11)-1(b) (2) (1961). See generally Rev. Rul. 63-117, 1963-1 Cum. Bull. 92, amplifying Rev. Rul. 56-366, 1956-2 Cunr. Butr. 976; Rev. Rul. 66-144, 1966-1 Cun. Buld. 91; Rev. Rul. 56-674, 1956-2 Cum. Bull. 293; Rev. Rul. 55-670, 1955-2 CuMr. BuLL. 233. 
have a negative effect upon any carryovers otherwise available to the acquiring corporation in an " $\mathrm{A}$ " or a " $\mathrm{C}$ " reorganization.

If the acquiring corporation assumes the seller's qualified deferred compensation plan for a brief period, and later terminates the plan, any otherwise available deduction carryovers will be limited. In the case of a pension plan, undeducted amounts may be deducted only under section 404 (a) (1)(C)..$^{26}$ In the case of a profit-sharing plan, the fifteen per cent limitation on carryover deductions will be based only upon the total compensation paid and accrued during the taxable year under review, to or on behalf of those employees who were participants during the final full year of the plan (ending upon the last day of the calendar month of termination) ${ }^{27}$ Thus, if all such employees leave the employ of the acquired corporation prior to the closing, or leave the acquiring corporation after the closing, no profit-sharing deduction carryovers will be available to the acquiring corporation. Furthermore, in the case of a profit-sharing plan, all unused contribution carryovers will become unavailable upon plan termination. ${ }^{28}$

If the seller discontinues its own deferred compensation plan prior to the closing, it is possible that any otherwise available carryover deductions will also become unavailable to the acquiring corporation on even a limited basis, because presumably section 381 (c) (11) means that the acquiring corporation will step into the shoes of the transferor

26 Treas. Reg. $\$ 1.381$ (c)(11)-1(d) (2) (1961) ("There are, however, special rules for computing the limitations on the amount of excess contributions which are deductible in a taxable year ending after the trust or plan has terminated ...."); Treas. Reg. $\$ 1.404$ (a)-7(b), T.D. 6534, 1961-1 CuM. BuLL. 145 ("In the case of a strcceeding taxable year of the employer which ends . . . after the trust or plan has terminated, such excess contributions are deductible to the extent of the limitation applicable to such year under section 404 (a) (1) (C) . . ."); Treas. Reg. \$1.404(a)6(b) (1), T.D. 6534, 1961-1 CuMr. BuIL. 145; Treas. Reg. $\$ 1.404$ (a)-4(d) (1961) ("The limitation under section $404(\mathrm{a})(1)(\mathrm{A})$ shall not be used for purposes of determining the amount deductible for a taxable year of the employer which ends . after the trust or plan has terminated."); Treas. Reg. $\$ 1.404$ (a)-5(e) (1961) " "The limitation under section 404 (a) (1) (B) shall not be used for purposes of determining the amount deductible for a taxable year of the employer which ends. after the trust or plan has terminated."); see Royer's, Inc. v. United States, $26 \dot{5} \dot{\mathrm{F}} 2 \mathrm{~d} \mathrm{~d} 615$ (3d Cir. 1959), rev'g 163 F. Supp. 225 (W.D. Pa. 1958); Cox, Corporate Acquisitions 432; Grayck, Employee Problems on Sale of a Business, N.Y.U. 23D INST. ON FED. TAX. 499,505 (1965) (noting the actuarial problems created by the limitation); Musto, supra note 20 , at 273 n.15.

27 Treas. Reg. $\$ \$ 1.381$ (c) (11)-1 (d) (2) (1961) ; Treas. Reg. $\$ 1.404$ (a)-9(b) (2), T.D. 6534, 1961-1 CUM. BULL. 145 ("In the case of a taxable year of the employer which ends . . . after the trust has terminated, the limitation shall be based on the compensation otherwise paid or accrued by the employer during such taxable year of the employer to the employees who, at any time during the one-year period ending on the last day of the last calendar month during which the trust was exempt under section 501 (a) , were beneficiaries of the trust funds accumulated under the plan."); Treas. Reg. \$1.404(a)-9 (e) (2), T.D. 6534, 1961-1 CuM. BuLx. 145; see Royers, Inc. v. United States, 265 F.2d 615 (3d Cir. 1959), rev'g 163 F. Supp. 225 (W.D. Pa. 1958) ; Rev. Rul. 54-270, 1954-2 CUM. Bull. 97 (expressing the government's previous position); Grayck, supra note 26, at 506: Musto, supra note 20 , at 271, 273 n.15.

28 Treas. Reg. $\$ 1.381$ (c) (11)-1(d) (3) \& (4) (1961) ; Treas. Reg. $\$ 1.404$ (a)9(a), T.D. 6534, 1961-1 CuM. BulL. 145; see Musto, supra note 20, at 273 . 
only if it continues the transferor's qualified deferred compensation plan. ${ }^{29}$

If, on the other hand, the acquiring corporation assumes and then continues to operate the seller's qualified deferred compensation plan on a nonqualified basis, the effect upon the otherwise available carryovers will be the same as though the buyer had actually terminated the seller's plan: there will be a termination in effect, if not in fact. ${ }^{30}$

Assuming, however, that full or limited carryovers will be available to the acquiring corporation under section 381 (c) (11) of the Code, a further requirement must be met before the deductions will be allowed. Section 404 authorizes contribution and deduction carryovers, but imposes the further limitation that all corporate deductions must meet the requirements of section $162,{ }^{31}$ i.e., deductible amounts must represent ordinary and necessary business expenses, or, in the context of a deferred compensation plan, "a reasonable allowance for salaries or other

29 See Musto, supra note 20, at 273-75, where the author concludes that if the acquired corporation terminates its own qualified plan, any carryover deductions will be available to the acquired corporation.

30 Treas. Reg. $\$ 1.381$ (c)(11)-1(d) (3) (1961) ("[T]he amount paid by the acquiring corporation will be deductible as an unused deduction carried over from the transferor or distributor corporation only if it is paid into the profit-sharing . . . trust established by the transferor or distributor corporation . . . in a taxable year of the acquiring corporation which ends with or within a year of such trust . . . for which it meets the requirements of section 401 (a) and is exempt under section 501 (a)."); Treas. Reg. \$1.404(a) 3(a), T.D. 6534, 1961-1 CuM. Bull. 145 ("In order to be deductible under section 404 (a) (1), contributions to a pension trust must be paid in a taxable year of the employer which ends with or within a year of the trust for which it is exempt under section 501(a). Contributions paid in such a taxable year of the employer may be carried over and deducted in a succeeding taxable year of the employer in accordance with section 404(a)(1)(D), whether or not such succeeding taxable year ends with or within a taxable year of the trust for which it is exempt under section 501(a). See $\$ 1.404$ (a) -7 for rules relating to the limitation on the amount deductible in such a succeeding taxable year of the employer.") ; Treas. Reg. $\$ 1.404(\mathrm{a})-7$ (b), T.D. 6534, 1961-1 Cum. Burr. 145 ("In the case of a succeeding taxable year of the employer which ends with or within a taxable year of the pension trust during which it is not exempt under section 501(a) ..., such excess contributions are deductible to the extent of the limitation applicable to such year under section 404(a) (1) (C) . . .") ; Treas. Reg. \$1.404(a)-6(b) (1), T.D. 6534, 1961-1 CuM. BuLL. 145; Treas. Reg. $\$ 1.404$ (a) -4(d) (1961); Treas. Reg. $\$ 1.404$ (a): 5 (e) (1961); Treas. Reg. $\$ 1.404$ (a)-9(b) (2), T.D. 6534, 1961-1 CuM. BuLl. 145 ("In the case of a taxable year of the employer which ends with or within a taxable year of the trust during which it is not exempt under section 501 (a) . . ., the limitation shall be based on the compensation otherwise paid or accrued by the employer during such taxable year of the employer to the employees who, at any time during the oneyear period ending on the last day of the last calendar month during which the trust was exempt under section 501(a), were beneficiaries of the trust funds accumulated under the plan."); Treas. Reg. \$1.404(a)-9(e) (2), T.D. 6534, 1961-1 Cunr. BuLL. 145 ; see Musto, supra note 20 , at 271 ; cf. TaX Managendent Portrolio No. 92-2d, supra note 22 , at $A-11$. The regulations under $\$ 381$ (c) (11) do not specifically provide that carryover deductions will be limited in the case of an nonqualified plan, but \$381(c) (11) does not expand the rights available under $\$ 404(\mathrm{a})$-it merely extends those rights to the acquiring corporation. Treas. Reg. $\$ 1.381(c)(11)-1(f)(1961)$

31 INT. REv. CODE of 1954, \$162. The regulations under $\$ 381$ (c) (11) provide that "to be deductible by reason of this section, contributions paid by the acquiring corporation must be expenses which otherwise satisfy the conditions of section 162. . . " Treas. Reg. \$1.381(c) (11)-1(f) (1961); see Charles E. Smith \& Sons Co. v. Commissioner, 184 F.2d 1011 (6th Cir. 1950); Treas. Reg. $\$ 1.404$ (a)-1(b) (1956). 
compensation for personal services actually rendered." 32 The regulations under section 404 indicate that deferred compensation plan contributions may be in the nature of additional compensation for services previously rendered; ${ }^{33}$ but query whether this provision covers past services rendered for an acquired corporation. Presumably it does not. $^{34}$ so that to the extent that any carryovers inherited by the acquiring corporation can be attributed only to services rendered for the acquired corporation, the carryovers would appear to be nondeductible. This would mean that no carryovers would be available to the acquiring corporation if the seller's plan covered only retired employees, or to the extent that the buyer did not continue the employment of seller's preacquisition employees. In illustrating section 381 (c)(11), however, the regulations provide that deductions will be allowed even though the seller's qualified deferred compensation plan covers only former employees. ${ }^{35}$ It would appear, then, that for purposes of the carryover provisions of the Code, reasonableness of compensation must be measured in terms of the services rendered for the employer corporation through the taxable year with respect to which the carryover contribution or deduction arose, by those participants covered under the plan during that taxable year. ${ }^{36}$ Presumably the statute of limitations will not bar this retrospective determination, because there would be no need for the government to consider the question of reasonable compensation until a taxpayer actually claims a deduction based upon a contribution or deduction carryover. ${ }^{37}$ Therefore, in those cases in which the buyer fails to examine the relationship of any carryovers to

32 INT. REV. CODE OF 1954, §162(a) (1).

33 Treas. Reg. $\$ 1.404(a)-1(b)$ (1956). See generally Lucas v. Ox Fibre Brush Co., 281 U.S. 115 (1930), aff'g 32 F.2d 42 (4th Cir. 1929), rev'g 8 B.T.A. 422 (1927).

34 See Rev. Rul. 62-139, 1962-2 CuM. BuLL. 123, where the government noted that under certain circumstances an employer could give an employee credit under its qualified pension plan for services rendered by the employee while in the employ of his former employer, but that the reasonable compensation question was to be measured in terms of services rendered by the employee for his present employer.

35 Treas. Reg. $\$ 1.381$ (c) (11)-1(b) (2) (1961) provides that:

[I]f the transferor corporation were to establish a qualified plan, and if the plan were maintained as a qualified plan by the acquiring corporation, then any contributions paid under the plan by the acquiring corporation (other than those which are deductible by the transferor corporation by reason of section 404 (a) (6)) would be deductible under section 404 by the acquiring corporation even though the plan were exclusively for the benefit of former employees of the transferor corporation.

See Musto, supra note 20 , at 272 ; Taft, supra note 4 , at 483-84.

36 See Rev. Rul. 67-341, 1967-2 Cum. Bur.. 156.

37 Rev. Rul. 67-341, 1967-2 CuM. BuLl. 156 suggests, however, that in the case of carryovers, the reasonable compensation question will be determined when the carryovers arise. If so, the 3-year statute of limitations, INT. REv. CODE OF 1954, $\$ 6501$ (a), will give the acquiring corporation some protection, unless (presumably) the acquired corporation did not file a Form 2950 (statement in support of its deferred compensation deduction) for the year or years in question. It is on this form that carryovers are noted. 
the services actually rendered by employees for the acquired corporation, carryovers may not be as valuable to the acquiring corporation as they might have originally appeared.

\section{2. " $\mathrm{B}$ " Reorganizations}

Section 381 (c)(11) does not apply to tax-free stock-for-stock acquisitions ${ }^{38}$ (so-called " $B$ " reorganizations ${ }^{39}$ ). Nevertheless, any unused contribution or deduction carryovers will be available to the acquired corporation on the same basis as that described above, ${ }^{40}$ as long as the acquired corporation is continued as a subsidiary of the buyer. Section 381 (c) (11) is not needed in the case of a pure " $\mathrm{B}$ " reorganization, for the acquired corporation will not lose its corporate identity, the only change being in the identity of its shareholders. ${ }^{11}$

\section{Taxable Reorganizations and Section 334(b) (2) Liquidations}

Because there are no Code provisions dealing specifically with unused contribution and deduction carryovers in a taxable reorganization or in a section 334(b) (2) liquidation preceded by a stock acquisition, presection 381 rules of construction ${ }^{42}$ will apparently apply. Although these rules are not well-defined, on the basis of the New Colonial Ice ${ }^{43}$ and Metropolitan Edison ${ }^{44}$ cases, it would appear that carryovers will be available only in the case of nontax-free mergers, consolidations, or stock-for-stock acquisitions. However, there is some indication that the acquiring corporation may also use the acquired corporation's carryovers if it can establish that the amounts claimed as a deduction repre-

38 Treas. Reg. $\$ 1.381$ (a)-1(b) (3) (i) (1960); Tax Managearent Portfolio No. 92-2d, supra note 22 , at A-5.

39 Int. Rev. CoDe of 1954, § 368(a) (1) (B).

40 See text accompanying notes $25-37$ supra.

41 Tax Management Portfolio No. 92-2d, supra note 22, at A-6. Treas. Reg. $\$ 1.381$ (a)-1(b) (3) (i) (1960) provides that:

In a case where section 381 does not apply to a transaction, item, or tax attribute . . ., no inference is to be drawn from the provisions of section 381 as to whether any item or tax attribute shall be taken into account by the successor corporation.

42 See PS No. 62, May 5, 1950, declared obsolete, Rev. Rul. 67-467, 1967-2 CuM. Buli. 432; TAX MANAGEMENT PortFolio No. 92-2d, supra note 22, at A-3; Lurie, Pensions After Mergers and Spin-Offs, 10 TAx L. Rev. 531, 534-35, 537-38 (1955) [hereinafter cited as Iurie, Pensions After Mergers].

43 New Colonial Ice Co. v. Helvering, 292 U.S. 435 (1934) (holding that a net operating loss was not available to the transferee corporation in the case of a purchase of corporate assets for stock).

44 Helvering v. Metropolitan Edison Co., 306 U. S. 522 (1939) (holding that in a statutory merger certain carryover deductions were available to the surviving corporation). See also Libson Shops, Inc. v. Koehler, 353 U. S. 382 (1957) ; Commissioner v. Phipps, 336 U. S. 410 (1949) ; Stanton Brewery, Inc. y. Commissioner, 176 F.2d 573 (2d Cir. 1949); Newmarket Manufacturing Co. v. United States, 233 F.2d 493 (1st Cir. 1956), cert. denied, 353 U. S. 983 (1957). 
sent its own ordinary and necessary business expenses..$^{45}$ If the acquiring corporation were forced to rely upon this latter alternative, plan termination could mean total loss of any otherwise available deduction carryovers ${ }^{46}$ (any contribution carryovers would, of course, be unavailable by reason of the termination ${ }^{47}$ ); while in the case of nontax-free mergers, consolidations, or stock-for-stock acquisitions, plan termination would limit any otherwise available carryovers, in the manner discussed above. ${ }^{48}$

The moral of the story is clear. If the to-be-acquired corporation has significant deduction or contribution carryovers, any efforts on the part of the buyer to restructure the proposed deal along tax-free and nonsection 334 (b) (2) oriented lines could prove rewarding. ${ }^{49}$

\section{Funding}

Unlike carryovers, which are significant in the case of both qualified pension and profit-sharing plans, questions of funding are relevant only to qualified pension plans. The basic concept of funding is quite simple: The conventional pension plan provides fixed benefits upon an employee's retirement. ${ }^{50}$ In order to have sufficient accumulated assets upon each employee's retirement to cover the cost of his retirement benefits, a certain level of plan funds is required each year..$^{51}$

\section{Underfunding}

Underfunding (evidenced perhaps by unrealized depreciation and skipped contributions) will occur when, on any reasonable actuarial

45 See Scovill Manufacturing Co. v. Fitzpatrick, 215 F.2d 567 (2d Cir. 1954), rev'g Civil No. 3234 (D. Conn., June 5, 1953), in which taxpayer corporation was allowed a business expense deduction on account of advances to a pension trust established by a corporation whose stock was acquired by the taxpayer corporation. The acquired corporation was liquidated after being operated as a subsidiary for approximately 5 years, at which time the taxpayer corporation formally took over the subsidiary's pension obligations. See TAX Management Portfolto No. 92-2d, supra note 22 , at $A-3$.

46 If the seller's plan were continued by the acquiring corporation in a taxable acquisition for only retired or terminated employees of the selling corporation, it would be difficult to establish that any deductions on account of said plan represented ordinary and necessary business expenses of the acquiring corporation. See authorities cited note 75 infra. See also text accompanying notes 31-37 supra.

47 Treas. Reg. \$1.404(a)-9(a), T.D. 6534, 1961-1 Cum. Buld. 145.

48 See text accompanying notes $26-29$ supra.

49 See Robbins, supra note 4, at 953.

$50 \mathrm{~A}$ so-called money purchase pension plan provides only those benefits available with the funds accumulated upon retirement for the benefit of each eligible employee. Many union plans are in effect money purchase pension plans.

51 The cost of an employee's past service credits may be spread over a period of 30 years, so that in some cases an employee's benefits will not be fully funded at retirement. In such event, the plan administrator may be required to use a portion of the funds accumulated for the benefit of other employees in order to cover the cost of the retired employee's benefits. For a general discussion of funding methods see Goodman, Funding Benefits Under Tax-Qualified Pension and Annity Plans, speech delivered at the San Francisco Chapter of the Western Pension Conference, San Francisco, Calif., Nov. 3, 1966, 3 CCH PEN. PlaN Gume, $\llbracket 29,000$, fif 29,026-29,035. 
basis, the funds accumulated on behalf of all plan participants at any one point in time are insufficient to cover the cost of their accrued retirement benefits. ${ }^{52}$ If the acquiring corporation elects to continue an underfunded pension plan, the annual cost of the plan will obviously be high, and an acquisition price adjustment might be appropriate. ${ }^{53}$ In the case of an " $\mathrm{A}$ " or a " $\mathrm{C}$ " reorganization, however, price adjustment should be analyzed carefully, for a price adjustment could affect the acquiring corporation's deductions on account of contributions to the seller's continued plan.

Section 381 (c) (16) (applicable to "A" and "C" reorganizations) provides that if the acquiring corporation assumes an "obligation" of the seller which gives rise to a "liability" after the closing, and such liability, if paid or accrued by the seller, would have been deductible by the seller on its applicable federal income tax return, then the acquiring corporation may deduct the liability when paid or accrued, unless the obligation was "reflected in the amount of stock, securities, or property transferred by the acquiring corporation to the transferor corporation for the property of the transferor corporation." 54 Several authors have suggested that despite section 381 (c) (11) of the Code, which deals specifically with pension and profit-sharing deductions following an " $A$ " or a "C" reorganization, section 381 (c) (16) may mean that if the acquiring corporation in an " $\mathrm{A}$ " or a " $\mathrm{C}$ " reorganization expressly assumes the seller's pension plan with a resulting price adjustment occasioned by significant underfunding, all posttransfer plan contributions on account of the underfunding will be nondeductible. ${ }^{55}$ The

52 See Cox, Corporate Acquisitions 416, 416 n.8; Wood, Pension Plans and Business Combinations-Part II, 3 MERGERs \& AcQ's 43, 45-46 (Sept.-Oct. 1968) [hereinafter cited as Wood, Pension Plans-Part II].

53 See B. Fox \& E. Fox, supra note 4, at \$2.02[3] [a] [i] ; Cox, Corporate Acquisitions 416; Wood, Pension Plans-Part I 21-22; Wood, Pension Plans-Part II 45-46. Wood suggests an alternative to price adjustment-the acquired corporation could contribute any unfunded past service costs to its qualified pension plan prior to the closing. Wood, Pension Plans-Part II 46. In the case of a stock acquisition (a " $\mathrm{B}$ " type reorganization), any carryover deductions would be available to the acquired corporation, while in the case of an assets acquisition, any carryovers would be available to the acquired corporation only if retained as a viable entity. Cf. Musto, supra note 20, at 273-75. See also Rev. Rul. 56-672, 1956-2 Cum. Bull. 295; Rev. Rui. 55-428, 1955-2 CuM. Bull. 230.

54 INT. REv. Code of 1954, §381 (c) (16) (emphasis added).

55 Cox, Corporate Acquisitions, supra note 4, at 418-20; Robbins, supra note 4, at 965-66; see Musto, supra note 20, at 271 n.1. The suggestion is based upon a Senate Finance Committee example, illustrating what became INT. REv. CoDE OF 1954, $\$ 381$ (c) (16). The example provides:

[I] $Y$ corporation transferred all its property to $X$ corporation in 1942 in a transaction which, if it had occurred after the effective date of part III, would have been a transaction described in subsection (a) (2), and $X$ corporation assumed an obligation of $Y$ corporation to make monthly pension payments directly to Y corporation's retired employees for as long as each should live, but such obligation was not taken into account in determining the amount of stock, securities, or property transferred by $X$ to $Y$ in exchange for ' $Y$ 's 
regulations under section 381 (c) (16) are not helpful, leaving open the question of the dual applicability of sections 381 (c) (11) and (c) (16) of the Code in the area of deferred compensation deductions following an " $A$ " or a " $C$ " reorganization. "se Looking at the words of the statute, however, it would appear that section 381 (c)(16) is inapplicable by its terms, for presumably underfunding represents a preclosing rather than a posttransfer liability. ${ }^{57}$ In addition, no language in section 381 (c) (16) suggests that it in any way modifies the former Code provision. 68

Underfunding may, however, have more serious implications than those involving plan costs and the acquisition price. A qualified pension plan must meet certain minimum funding standards. ${ }^{59}$ Specifically, plan benefits must at all times be available to eligible participants, and the unfunded past service costs of the plan (including any unfunded prior normal costs and interest on unfunded costs) may at no time exceed the unfunded past service costs of the plan upon its effective date. ${ }^{60}$ If these conditions cannot be met, the government may withdraw its prior approval of the seller's plan, ${ }^{01}$ and will, in any event,

property, then $\mathrm{X}$ corporation can deduct in taxable years beginning after December 31, 1953, the payments made in each such year to $Y^{\prime}$ 's retired employees.

S. Rep. No. 1622, $83 d$ Cong., 2d Sess. 283 (1954). An almost identical example is found in H.R. REp. No. 1337, 83d Cong., 2d Sess. A142 (1954).

56 Treas. Reg. $\$ 1.381$ (c) (16)-1(a) (1) (1964), restating the statute, provides that:

[I]n the case of a transaction to which section 381(a) (2) applies, then section 381 (c) (16) shall not apply to an obligation which is reflected in the amount of consideration, that is, the stock, securities, or other property, transferred by the acquiring corporation to a transferor corporation or its shareholders in exchange for the property of that transferor corporation. An obligation which is so reflected in the amount of consideration will be treated as an item or tax attribute not specified in section 381 (c) (16).

57 See also Cox, Corporate Acquisitions, supra note 4 , at 420 n.20, in which it is suggested that pension plans do not represent an "obligation" as the term is used in $\$ 381$ (c) (16).

58 See TAx Managearent Portfolio No. 92-2d, supra note 22, at A-19.

59 Rev. Rul. 69-421, Part 2(b), 1969 INT. REv. Bulc. No. 32, at 8, provides that "minimum funding requirements must be maintained even if contributions are made by employees only." See Young, Miscellaneous Problems Involving Suspension and Termination of Pension Plans, 15 Western Reserve L. Rev. 667, 673-74, 677-79 (1964) [hereinafter cited as Young, Miscellaneons Problems].

60 Treas. Reg. \$1.401-6(c) (2) (ii) (1963) ; Rev. Rul. 69-421, Pt. 6(d) (1), 1969 INT. REv. Bull. No. 32, at 36; Rev. Rul. 56-596, 1956-2 CuM. Bull. 288, modifying Rev. Rul. 55-186, 1955-1 Cum. BuLl. 39; Rev. Rul. 55-480, 1955-2 Cum. BuLL. 227; PS No. 57, Aug. 5, 1946, modified, Rev. Rul. 56-596, 1956-2 Cum. Bul. 288; see Goodman, questions following speech delivered at Annual Meeting of the Association for Advanced Life Underwriting, Washington, D.C., Mar. 11, 1968, 3 CCH PEN. PLAN GUIDE |f 29,623, question 47.

61 See Rev. Rul. 56-596, 1956-2 Cum. BuLc. 288, modifying Rev. Rul. 55-186, 1955-1 Cum. Bull. 39; PS No. 57, Aug. 5, 1946, modified, Rev. Rul. 56-596, 1956-2 Cunr. BuLl. 288. For a discussion of the relationship between the government's "termination rule," text accompanying notes 87-94 infra, and a technical termination caused by underfunding see Young, Miscellaneous Problems 686-88. 
require full vesting, ${ }^{62}$ thereby eliminating to some extent the possibility of a reduction in plan costs by way of forfeitures. An underfunded plan may thus be a serious candidate for termination.

\section{Overfunding}

Overfunding, evidenced perhaps by full past service funding, unrealized fund appreciation, and accumulated insurance dividends, ${ }^{63}$ should produce an effect opposite to that produced by underfunding. ${ }^{04}$ On a short range basis an overfunded plan may mean lower plan costs. In the long run, there may be an additional bonanza-if the plan is subsequently terminated, and if, after satisfaction of all accrued and fixed liabilities, there is a surplus in the fund, the surplus will revert to the employer. ${ }^{65}$ The reversion will be taxable to the employer, ${ }^{66}$ but will represent "actual" income if attributable to an overfunding inherited from the acquired corporation without a corresponding increase in the acquisition price.

\section{Technical Termination}

If the acquiring corporation decides upon plan termination, as opposed to continuation, it will, by reason of the full vesting requirements of the Code, ${ }^{67}$ lose the benefit of valuable forfeitures in the case of a profit-sharing plan or of any overfunding in the case of a pension plan (unless there is a surplus in the fund and the acquiring corporation briefly assumes the obligations of the seller under its qualified plan).

The acquiring corporation may find, however, that the results differ in no respect upon plan continuation, a factor that could affect

62 Treas. Reg. $\$ 1.401-6$ (a) (1) \& (c) (1963) ; Rev. Rul. 69-421, Pt. 6(d), 1969 INT. REV. BuLL. No. 32, at 36. "A suspension is a temporary cessation of contributions which may ripen into a discontinuance. . . In such case, vesting of employees' rights is required." 1969 INT. REv. BULL. No. 32, at 36.

63 See Rev. Rul. 69-421, Pt. 2(r), 1969 INT. REv. Bull. No. 32, at 18 (discussing contingency or surplus reserves created by the accumulation of insurance dividends); Rev. Rul. 67-365, 1967-2 CuM. Bull. 154 and Rev. Rul. 59-153, 1959-1 CuMr. Buld. 89 (dealing with gains caused by conservative funding assumptions); Wood, Pension Plans-Part II 46 (discussing the impact of fund assets valued at cost).

64 For a discussion of the impact of overfunding upon an acquisition price see Cox, Corporate Acquisitions, supra note 4, at 417; Wood, Pension Plans-Part II 46. 65 Treas. Reg. $\$ 1.401-2$ (b) (1) (1956) ; Rev. Rul. 69-421, Pt. 3(d), 1969 INT. Rev. Bull. No. 32, at 20.

${ }_{66}$ Cf. Rev. Rul. 55-629, 1955-2 Cum. Bull. 588.

67 INT. Rev. CoDE of $1954, \S 401$ (a) (7) provides that:

A trust shall not constitute a qualified trust . . . unless the plan of which such trust is a part provides that, upon its termination or upon complete discontinuance of contributions under the plan, the rights of all employees to benefits accrued to the date of such termination or discontinuance, to the extent then funded, or the amounts credited to the employees' account are nonforfeitable.

See Treas. Reg. \$1.401-6(a) (1963) ; Rev. Rul. 69-421, Pt. 6(a), 1969 Int. Rev. BuLl. No. 32, at 34; Grayck, supra note 26 , at 499 . 
its decision regarding termination. The regulations ${ }^{6 s}$ and several authors ${ }^{69}$ suggest that if only a small number of participants employed by the selling corporation become employees of the acquiring corporation, or remain in the employ of the acquired corporation after it becomes a subsidiary of the buyer, the government may take the position that there has been a plan termination in effect, if not in fact, thereby bringing into play the full vesting provisions of the Code and regulations. The effect could be the same if the acquiring corporation adopted the seller's qualified deferred compensation plan with a resulting influx of new participants not formerly employed by the selling corporation. ${ }^{\mathbf{7 0}}$ It would be both rational and equitable for the government to take such a position, for it would seem that only employees of the acquired corporation should benefit from that corporation's contributions to its qualified deferred compensation plan.

\section{E. Deduction for Past Service Credits}

If the seller has a qualified pension plan, the acquiring corporation should be concerned whether, in the event of plan continuation on a nondiscriminatory basis, it will be able to deduct its own contributions to the plan on account of past service credits accrued by transferred employees while on the payroll of the selling corporation.

The answer is an unqualified yes in the case of stock-for-stock acquisitions, where the acquired corporation does not lose its own identity (although the deduction must be claimed on the newly acquired subsidiary's tax return). In the case of other acquisitions, however, the applicable revenue rulings ${ }^{71}$ indicate that a successor corporation

68 Treas. Reg. $\$ 1.401-6($ b) (1) (1963) provides that:

Whether a plan is terminated is generally a question to be determined with regard to all the facts and circumstances in a particular case. For example, a plan is terminated when, in connection with the winding up of the employer's trade or business, the employer begins to discharge his employees.

69 See Cox, Corporate Acquisitions, supra note 4, at 433; Robbins, supra note 4, at 967; Rustigan, supra note 4, at 283-84; Taft, supra note 4, at 477, 480; cf. Cox, Amendments, supra note 7, at 1212-13.

${ }^{70}$ See Robbins, supra note 4, at 967; Taft, supra note 4, at 480. For a discussion of the carryover problem see note 159 infra. But see Robbins, supra note 4, at 965; Taft, supra note 4 , at 479.

71 Treas. Reg. $\$ 1.381$ (c) (11)-1(g) (1961) provides that:

In computing the cost of past service credits under a plan with respect to employees of the distributor or transferor corporation, the acquiring corporation may include the cost of credits for periods during which the employees were in the service of the distributor or transferor corporation.

See also Special Ruling, Oct. 23, 1944, Norman D. Cann, Deputy Commissioner, 2 CCH PEN. PlaN GuIDe $\uparrow 12,902$.

But Rev. Rul. 69-421, Pt. 4(s), 1969 INT. Rev. Bull. No. 32, at 28, in effect provides that the cost of credits for past service with a former employer can be deducted only if certain conditions are met: (1) The former employer must be designated in the plan. (2) All employees having such past service must be treated alike. (3) The use of such past service credits cannot produce discrimination in favor of the prohibited group (officers, shareholders, and highly paid or supervisory personnel, 
may deduct the current cost of past service credits attributable to service with a predecessor only under a stated set of circumstances.

First, the former employer must be specified in the continued plan. $^{72}$ Second, the past service credits for which the acquiring corporation claims a deduction may not represent a duplication of benefits. $^{73}$ Duplication would undoubtedly occur if the predecessor's plan were terminated prior to the closing with full vesting, so that it might be replaced with the acquiring corporation's already existing plan; but duplication should not occur if the predecessor's plan were simply continued by the acquiring corporation.

Finally, and most significantly, all deductions must represent " $a$ reasonable allowance for salaries or other compensation for personal services actually rendered," under section 162 of the Code. ${ }^{74}$ For these purposes, reasonableness must, with one exception, be measured in terms of the services rendered by participating employees for the acquiring corporation. ${ }^{75}$ The exception occurs in the cases of " $\mathrm{A}$ " and " $C$ " reorganizations, where reasonableness may apparently be measured in terms of the services actually rendered by participating employees for both the acquired and acquiring corporations, as long as the past service contributions are made pursuant to the plan originally established by the acquired corporation. ${ }^{76}$ This latter provision may be further inducement for a tax-free or nonsection $334(\mathrm{~b})(2)$ oriented deal. ${ }^{77}$

\section{Should the Seller's Plan Be Terminated?- The Seller's Point of View \\ A. Discrimination on Plan Termination}

Section 401 (a) (4) of the Code provides that the benefits or contributions provided under a qualified deferred compensation plan cannot

INT. REv. CoDE of 1954, $\$ 401$ (a) (3) (B) \& (4)). (4) There can be no duplication of benefits. (5) The contributions on account of past service credits must represent ordinary and necessary business expenses under INT. REv. CODE OF 1954, §162(a) (1). Accord, Rev. Rul. 62-139, 1962-2 Cum. BulL. 123; see Cox, Corporate Acquisitions, supra note 4, at 422 \& $n .26$; Robbins, supra note 4, at 958, 966; Rustigan, supra note 4, at 286-87. For a discussion of deductions on account of past service credits accrued by retired or former employees of the acquired corporation see Duncan, supra note 7 , at 1202; Taft, supra note 4, at 478-79.

72 Rev. Rul. 69-421, Pt. 4(s), 1969 INT. Rev. Bull. No. 32, at 28; Rev. Rul. 62-139, 1962-2 CUM. Bull. 123.

73 Rev. Rul. 69-421, Pt. 4(s), 1969 Int. Rev. Butr. No. 32, at 28; Rev. Rul. $62-139,1962-2$ Cun. BuLL. 123; see Goodman, Reorganizations, supra note 21, at 165 ; Taft, supra note 4 , at 478 .

74 Int. Rev, CoDE of 1954, §162(a) (1).

75 Rev. Rul. 62-139, 1962-2 CuMr. Bull. 123; see Goodman, Reorganizations, supra note 21, at 165; Scheff, Qualified Pension Plans: Discrimination; Deductibility of Contributions; Taxability of Distributions; Separation from Service, N.Y.U. 26TH INST. ON FED. TAX. 1027, 1047 (1968).

76 See Treas. Reg. $\$ 1.381$ (c) (11)-1(b) (2) (1961); note 35 supra.

77 For a discussion of the possible applicability of INT. REv. CODE of 1954, $\$ 381$ (c) (16) see text accompanying notes 54-58 supra; Robbins, supra note 4, at 958 . 
discriminate in favor of officers, shareholders, highly compensated employees, and persons whose principal duties consist in supervising the work of other employees. ${ }^{78}$ This rule applies not only during the life of a qualified plan, but also upon its termination. ${ }^{79}$ Therefore, if the benefits available to participants upon termination of a qualified deferred compensation plan discriminate in favor of the prohibited group, distributees will no longer have available to them the special long-term capital gain-“forward" averaging provisions of the Code, which apply only in the case of lump-sum distributions from a qualified, as opposed to a nonqualified, employee benefit plan. ${ }^{80}$ However, the (1956).

78 INT. Rev. Code of 1954, §401(a) (4); see Treas. Reg. $\$ 1.401-1$ (b) (1) (ii)

79 Rev. Rul. 69-24, 1969 INT. Rev. Burc. No. 4, at 9, 10, superseding Mim. 6136, 1947-1 Cun. Bull. 58; Rev. Rul. 69-25, \$ 4.01, 1969 INT. Rev. Bull. No. 4, at 15, superseding PS No. 7, July 29, 1944 \& PS No. 52, Aug. 9, 1945; see Marjorie F. Birnie, 12 T.C.M. 867 (1953).

80 INT. Rev. Code of 1954, §402(a) (2), dealing with capital gains treatment for certain deferred compensation distributions, applies only to qualified distributions from "an employees' trust described in section $401(\mathrm{a})$, which is exempt from tax under section 501 (a)."

Section 402(a) (5), added by the Tax Reform Act of 1969, Pub. L. No. 91-172, $\$ 515$ (a) (1), 83 Stat. 643-44, limits the availability of long term capital gains treatment under $\$ 402(a)(2)$ of the Code, as follows:

(5) IIMITATION ON CAPITAL GAINS TREATMENT.-The first sentence of paragraph (2) shall apply to a distribution paid after December 31, 1969, only to the extent that it does not exceed the sum of-

(A) the benefits accrued by the employee on behalf of whom it is paid during plan years beginning before January 1, 1970, and

(B) the portion of the benefits accrued by such employee during plan years beginning after December 31, 1969, which the distributee establishes does not consist of the employee's allocable share of employer contributions to the trust by which such distribution is paid.

The Secretary or his delegate shall prescribe such regulations as may be necessary to carry out the purposes of this paragraph.

Query what the term "benefits accrued" means, as used in $\$ 402$ (a) (5) (A). For example, suppose $Y$ 's account balance equals $\$ 1,000$ (valued at market) on December 31,1969 , and thereafter the market declines, so that said $\$ 1,000$ is worth only $\$ 800$. Suppose further that $Y$ leaves the employ of his employer and receives as a plan distribution, $\$ 1,000$, consisting of $\$ 800$ (the depreciated value of his December 31,1969 account balance) and $\$ 200$ (the value of post-December 31, 1969 employer contributions on his behalf). Will $Y$ be entitled to long-term capital gains treatment, assuming that the general conditions of $\$ 402$ (a) (2) can be met, with respect to $\$ 1,000$ or only $\$ 800$ ?

Any taxable amounts which do not qualify for long-term capital gains treatment under $\$ 402(\mathrm{a})(5)$ of the Code will qualify for "forward" averaging under $\$ 72(\mathrm{n})$, as amended by the Tax Reform Act of 1969, provided that the employee for whom benefits were accrued participated in the distributor plan for at least 5 taxable years prior to the taxable year of distribution. Section $72(\mathrm{n})(4)$, added by the Tax Reform Act of 1969, Pub. L. No. 91-172, $\$ 515$ (b) (2), 83 Stat. 645 , provides as follows:

(4) SPECIAL RULE FOR EMPLOYEES WITHOUT REGARD

TO SECTION 401 (c) (1).-In the case of amounts to which this subsection applies which are distributed or paid with respect to an individual who is an employee without regard to section 401 (c) (1), paragraph (2) shall be applied with the following modifications:

(A) "7 times" shall be substituted for " 5 times", and "14 2/7 percent" shall be substituted for "20 percent".

(B) Any amount which is received during the taxable year by the employee as compensation (other than as deferred compensation within the meaning of section 404) for personal services performed for the 
employer corporation may escape penalty. Presumably, any plan disqualification would relate only to the final year of the plan, so that previously claimed deductions would not be affected, ${ }^{81}$ while contributions with respect to the final year of the plan would probably be deductible in full under section 404 (a) (5) of the Code, ${ }^{82}$ dealing with contributions to a nonqualified plan.

In the case of profit-sharing plans, discrimination upon plan termination is likely to occur when only a few active and highly paid participants remain to reap the benefit of past forfeitures through the one hundred per cent vesting provision. ${ }^{83}$ Perhaps the only solution to

employer in respect of whom the amounts distributed or paid are received shall not be taken into account.

(C) No portion of the total distributions or amounts payable (of which the amounts distributed or paid are a part) to which section 402 (a) (2) or 403 (a) (2) (A) applies shall be taken into account.

Subparagraph (B) shall not apply if the employee has not attained the age of $59 \mathrm{r} / 2$ years, unless he has died or become disabled (within the meaning of subsection $(\mathrm{m})(7))$.

INT. REv. CODE of $1954, \S 72(\mathrm{n})(2)$ provides that:

(2) LIMITATION OF TAX.-In any case to which this subsection applies, the tax attributable to the amounts to which this subsection applies for the taxable year in which such amounts are received shall not exceed whichever of the following is greater:

(A) 5 times the increase in $\operatorname{tax}$ which would result from the inclusion in gross income of the recipient of 20 percent of so much of the amount so received as is includible in gross income, or

(B) 5 times the increase in tax which would result if the taxable income of the recipient for such taxable year equaled 20 percent of the amount of the taxable income of the recipient for such taxable year determined under paragraph (3) (A).

81 See Seligman, Jr., supra note 10, at 361-62. But of. Rev. Rul. 69-25, §4.04, 1969 INT. Rev. BuLc. No. 4, at 15-16.

\$2 INT. REv. CODE of 1954, \$ 404(a) (5), as amended by the Tax Reform Act of 1969, Pub. L. No. 91-172, \$321(b) (3), 83 Stat. 591, provides that contributions to a nonqualified deferred compensation plan will be deductible "[i]n the taxable year in which an amount attributable to the contribution is includible in the gross income of employees participating in the plan, but, in the case of a plan in which more than one employee participates only if separate accounts are maintained for each employee." INT. Rev. Code of 1954, \$ 83, added by the Tax Reform Act of 1969. Pub. L. No. 91$172, \$ 321$ (a), 83 Stat. 588-90, and INT. REv. CODE OF 1954, \$402(b), as amended by the Tax Reform Act of 1969, Pub. L. No. 91-172, §321(b), 83 Stat. 590-91, govern the tax treatment of contributions for employees participating in a nonqualified deferred compensation plan. See Seligman, Jr., supra note 10 , at 362 .

83 Cf. Sherwood Swan \& Co., 42 T.C. 299 (1964), aff'd, 352 F.2d 306 (9th Cir. 1965), not acquiesced in, Rev. Rul. 66-251, 1966-2. CuM. BulL. 121; Ryan School Retirement Trust, 24 T.C. 127 (1955), acquiesced in, 1955-2 Cum. Bunl. 9. At the inception of the Ryan trust, 115 employees (including 5 in the prohibited group) were eligible to participate. One year later, however, there were only 29 active participants, 86 having ceased to be employees; and the following year, there were only 13 participants, including the same 5 members of the prohibited group. A few additional employees later joined the plan, but by October 31, 1951, there were only 10 participants. By the seventh year $58 \%$ of all trust funds had been allocated to members of the prohibited group, although the comparable first year allocation was only $8.4 \%$. Despite the government's argument that the plan was discriminatory in operation, the court held: "If there is any discrimination here, it would seem to be in favor of the permanent employees as against the impermanent employees, but that is not the type of discrimination contemplated by the statute." 24 T.C. at 134 . It is doubtful that the same result would prevail today. See Greenwald v. Commissioner, 366 F.2d 538 (2d Cir. 1966), aff'g in part \& rev'g in part, 44 T.C. 137 (1965). 
this problem would be a plan amendment calling for the redistribution of forfeitures among previously terminated participants. Such an amendment, however, would not be particularly palatable to the principals of the acquired corporation.

In the case of pension plans, the discrimination problem is more complex, due in part to the various ways in which fund assets may be allocated among participating employees. ${ }^{84}$ One popular method of fund distribution requires the purchase of retirement benefits for those who have attained their normal retirement age and the application of any remaining assets for the benefit of those participants approaching normal retirement. For example, benefits could first be purchased for those within five years of normal retirement, then for those within ten years of normal retirement, and so on down the line. ${ }^{85}$ The problem here is that members of the prohibited group are apt to come out ahead of the game, because they are likely to be the older employees of the employer corporation. ${ }^{80}$

Having become aware of this problem, the government devised the so-called "termination rule," 87 which, with certain limited exceptions, must be included in all newly established pension plans. ${ }^{8 s}$ Although the

S4 For example, priority may be given to beneficiaries over the age of 50 at the time of plan termination, or to those who have met certain minimum age and service requirements, or to those who have completed at least 10 years of continuous employment. Rev. Rul. 69-421, Pt. 6(b), 1969 INT. Rev. Bull. No. 32, at 35; Treas. Reg. $\$ 1.401-6$ (a) (2) (ii) (1963); see Young, Miscellaneonts Problems 716. An allocation provision may be included in the plan at its inception or may be added by way of amendment prior to termination. Treas. Reg. $\$ 1.401-6(a)(2)$ (i) (1963).

S5 See Rev. Rul. 69-421, Pt. 6(b), 1969 Int. Rev. BuLl. No. 32, at 35; Young, Treasury Mimeograph 5717-Government Rules Restricting Disbursements on Termination of a Pension Plan, 15 WESTERN RESERve L. REv. 534, 536-37 (1964) [hereinafter cited as Young, Minneo 5717].

86 See Cox, Corporate Acquisitions, supra note 4, at 428 n.51; cf. Goodman, Permanency as a Requisite of Tax Qualified Pension and Profit-Sharing Plans, 39 Taxes 42, 47 (1961) [hereinafter cited as Goodman, Permanency].

87 Treas. Reg. $\$ 1.401-4$ (c) (2) (1963) ; Rev, Rul. 69-421, Pt. 6(c), 1969 INT. Rev. BuLl. No. 32, at 35. The "termination rule" was first described in Mim. 5717, 1944 Cum. Bull. 321, modified, Rev. Rul. 61-10, 1961-1 Cum. Bull. 143, and PS No. 8, Aug. 4, 1944, modified, Rev. Rul. 65-294, 1965-2 CuM. Bull. 136, and was further explained in PS No. 25, Sept. 2, 1944; PS No. 29, Sept. 16, 1944; PS No. 31, Sept. 16, 1944; PS No. 38, Oct. 7, 1944; and PS No. 42, Nov. 11, 1944. Each Mim. and PS, with the exception of PS' No. 31, was declared obsolete by Rev. Rul. 67-467, 1967-2 Cum. BuLL. 432. For a concise explanation of the rule see Goodman, Permanency 48-49; Goodman, Termination of Pension, Profit-Sharing and Stock Bomus Plans, 32 TAxes 48, 53 (1954) [hereinafter cited as Goodman, Termination]. 88 Treas. Reg. $\$ 1.401-4$ (c) (1), T.D. $6675,1963-2$ CuM. BulL. 151, provides that:

[A] qualified pension plan must expressly incorporate provisions which comply with the restrictions contained in subparagraph (2) of this paragraph at the time the plan is established, unless (i) it is reasonably certain at the inception of the plan that such restrictions would not affect the amount of contributions which may be used for the benefit of any employee, or (ii) the Commissioner determines that such provisions are not necessary to prevent the prohibited discrimination that may occur in the event of any early termination of the plan.

See Young, Mimeo 5717 540-42, who argues that the "termination rule" may not deal effectively with the problem of discrimination. 
rule is extremely complex, it provides basically that if a plan is terminated within ten years of its effective date, the amount available for the benefit of an employee (described below) cannot exceed the greater of $\$ 20,000$ or an amount determined under the following formula: twenty per cent of the first $\$ 50,000$ of the employee's annual compensation, times the number of years between the plan's inception and termination, or, if earlier, the date on which the full current costs of the plan were not met. Employees covered by the "termination rule" are those who were among the twenty-five highest paid employees of the employer upon the inception of the plan and whose annual pension upon normal retirement would have been in excess of $\$ 1,500$.

Application of the "termination rule" may require a redistribution of fund assets upon plan termination, ${ }^{89}$ following an initial application of the basic distribution rules set forth in the plan. While redistribution may cure any problem of discrimination, ${ }^{20}$ it may also be unpalatable to the key employees of the acquired corporation, who might prefer plan continuation.

On occasion, the government has permitted a corporation to delete the "termination rule" prior to an anticipated plan termination, ${ }^{11}$ but it appears that deletion will be permitted only when (a) corporate liquidation is the cause of the anticipated termination, (b) all past service costs have been fully funded, and (c) the ratio of benefits to current compensation per year of service is nondiscriminatory. ${ }^{92}$ It is almost certain, therefore, that deletion would be unauthorized in the context of stock-for-stock acquisitions. Deletion might also be prohibited in the case of certain statutory mergers, consolidations, and stock-for-assets transactions, where the corporate liquidation is merely

89 Rev. Rul. 65-294, 1965-2 CUM. BuLL. 136, provides that any amounts unallocable to restricted employees under the "termination rule" must be used to cover the cost of benefits accrued by unrestricted employees, and only then may any excess be applied against the cost of benefits accrued by restricted employees.

90 Treas. Reg. $\$ 1.401-4$ (c) (1), T.D. 6675, 1963-2 Cumr. Bull. 151, provides that even though the "termination rule" becomes operative upon a plan termination, "the plan may in operation result in the discrimination prohibited by section 401 (a) (4), unless other provisions are - . incorporated in the plan." Rev. Rul. 69-25, \$ 4.02, 1969 INT. REv. Bur.. No. 4, at 15, also provides that application of the "termination rule" does not preclude a finding of discrimination. See Rev. Rul. 69-24, Ex. 4, 1969 INT. Rev. Bull. No. 4, at 12-13; Goodman, Termination 53; Seligman, Jr., supra note 10 , at $361-62$.

91 Rev. Rul. 59-241, 1959-2 Cum. Bull. 118. "Disqualification would not necessarily result from the deletion, from a plan, of provisions giving effect to the limitations set forth in Mimeograph 5717 ..., if such limitations were replaced by provisions requiring an allocation of benefits among the participants on a basis which will not result in the prohibited discrimination or if the deletion will not result in such discrimination." Id. 119; see Goodman, Permanency 50; Young, Mimeo 5717, at 552.

$\$ 2$ Rev. Rul. 59-241, 1959-2 Cum. BuLc. 118, 120 notes that the termination rule may be unnecessary in a corporate liquidation, where the employer's business ceases, because future service credits are unavailable by reason of the discontinuance of employees' services, rather than by reason of a plan termination. See Cox, Corporate Acquisitions, supra note 4, at $428 \mathrm{n} .51$; Goodman, Reorganizations 167; Musto, supra note 20, at 275-76; Young, Mimeo 5717, at 539-40. 
technical in nature, and the employees of the acquired corporation become employees of the successor enterprise. ${ }^{.3}$

Generally speaking, the "termination rule" will not apply after a qualified plan has been in effect for ten full years, ${ }^{94}$ but a subsequent plan termination would still be subject to the the nondiscrimination requirements of the Code and could be the occasion for a redistribution of assets that would take funds away from the prohibited group. ${ }^{95}$

Therefore, from the point of view of the selling corporation, plan termination may not be an attractive alternative, particularly if termination means significantly reduced benefits for its key personnel.

\section{B. Permanency}

In addition to being nondiscriminatory, a qualified plan must be permanent, ${ }^{96}$ in the sense that termination may not be anticipated at the plan's inception. ${ }^{97}$ The penalties for violation of the permanency requirement (disqualification and its impact) will affect not only participating employees but also the acquired corporation, which may conclude that termination is an unattractive and unacceptable alternative, in the absence of an acquisition price adjustment. ${ }^{98}$ As in the

93 See Dederick, What constitutes discrimination in pension and profit-sharing plans? 22 J. TAXation 272, 274 (1965); Goodman, Permanency 50 : "In unusual situations, however, where advance funding has fully provided benefits for the lowerpaid employees, it may be possible to release the restrictions for those subject thereto, provided, however, that the prohibited discrimination does not exist."

94 The rule will apply, however, if benefits become payable after a qualified plan has been in effect for 10 full years and the full current costs of the plan for the first 10 years have not been funded. Treas. Reg. $\$ 1.401-4$ (c) (2) (ii) (c) (1963).

95 Cf. Rev. Rul. 55-60, 1955-1 Cum. Bull. 37, where discrimination was not found on a plan termination more than 10 years after the plan's inception, due to adverse and unforeseen business conditions. The ratios of benefits to total compensation were as follows: $33 \%$ controlling stockholders, $21 \%$ minority stockholders, $17 \%$ highly paid, non-stockholder employees, $11 \%$ other employees. It is unlikely that this ruling would apply to a foreseeable plan termination. See Gordon, supra note 11, at 1177-78 (1956). For a discussion of permanency in connection with Rev. Rul. 55-60 see text accompanying notes 96-120 infra.

96 Treas. Reg. $\$ 1.401-1$ (b) (2), T.D. 6675, 1963-2 Cum. Bull. 151; Rev. Rul. 69-421, Pt. 2(h), 1969 INT. REv. Bunz. No. 32, at 10 ("A qualified plan is a permanent and continuing program."); Rev. Rui. 69-24, 1969 INT. REv. BuLL. No. 4, at 9, 10, superseding Mim. 6136, 1947-1 CUM. BuLL. 58; Rev. Rul. 69-25, \$2.02, INT. REv. BuLL. No. 4, at 14, superseding PS No. 7, July 29, 1944 \& PS No. 52, Aug. 9, 1945, modified, Rev. Rul. 55-60, 1955-1 CuM. BuLL. 37.

97 The permanency rule was adopted so that employers could not adopt a qualified plan in high profit years, reap the benefit of an additional income tax deduction, and then terminate the plan before other employees could qualify for benefits. PS No. 7, July 29, 1944, superseded, Rev. Rul. 69-25, 1969 INT. Rev. BuLx. No. 4, at 14; Goodman, Permanency 46; see Rev. Rul. 69-24, Sit. 3, 1969 Int. Rev. Bun. No. No. 4, at 11-12; Rev. Rul. 69-25, \$2.02, 1969 INr. Rev. BuLL. No. 4, at 14; Young, SalariedOnly Plan, 106 Trusts \& Estates 819, 821 (1967) [hereinafter cited as Young, Salaried-Oilly Plan].

38 The government must be notified of all plan terminations, so that a determination may be made regarding the issues of permanency and discrimination. Treas. Reg. \$1.401-1 (b) (2), T.D. 6675, 1963-2 CUM. BuLL. 151; Rev. Rul. 69-25, \$2.03, 1969 INT. Rev. Bulz. No. 4, at 14; Rev. Rul. 68-252, 1969 INT. Rev. Bull. No. 20, at 10, superseding PS No. 56, June 27, 1946. For a list of the information that must be submitted to the government with a formal determination letter request see Rev. Proc. $69-4, \$ 4.04,1969$ INT. Rev. BuLd. No. 1, at 21. 
case of plan discrimination, the special long-term capital gain-"forward" averaging provisions of the Code will be unavailable to the recipients of a lump-sum distribution. ${ }^{99}$ Because the resultant plan disqualification will be both current and retroactive in nature, any previously claimed corporate deductions on account of plan contributions for prior open years may also be disallowed; ${ }^{100}$ while any accompanying trust, theretofore exempt, will be taxable on all nonexempt income realized during open years, ${ }^{101}$ which could exceed the normal three, if the trust had consistently failed to file annual information returns with the federal government. ${ }^{102} \mathrm{~A}$ tax on trust income would, of course, mean reduced distributions for terminated employees.

The government uses two criteria to determine whether a terminated plan was established as a permanent program for the benefit of employees in general: if the initial employer or successor corporation terminates a qualified plan "within a few years" after its effective date, without a "valid business reason" 103 or for no apparent "business necessity," 104 the government will assume that the plan was impermanent from its inception, unless the employer can overcome the presumption with affirmative evidence. ${ }^{105}$

Although the phrase "within a few years" has not been defined in any published regulation or revenue ruling, several conclusions regarding the phrase can nevertheless be drawn from the available materials. First, it would appear that the termination of a qualified plan more than ten years after its effective date will be safe from attack on grounds of impermanence, partly because ten years is a significant period of time, and partly because ten is the significant number in the govern-

90 An impermanent plan would not be exempt from tax under INT. Rev. CoDE of $1954, \$ 501$ (a), so that distributions would not qualify under INT. REv. CODE OF 1954, $\S \S 402(\mathrm{a})(2)$ and $72(\mathrm{n})$. See note 80 supra.

100 See Seligman, Jr., supra note 10, at 362; Young, Miscellaneons Problems 693.

101 See Cox, Corporate Acquisitions, supra note 4, at 427; Seligman, Jr., supra note 10 , at 362 .

102 If a deferred compensation trust files an annual information return with the government on Form 990-P, under INT. REv. CODE of 1954, $\$ 6033$ (a), and in good faith believes that it is exempt from taxation, the return will start the running of the statute of limitations under INT. REv. CODE of 1954, §6501(a). INT. REv. CoDE of 1954, § 6501 (g) (2) ; Rev. Rul. 60-144, 1960-1 Cur. Bul.. 636; see Rev. Rul. 69-247, 1969 INT. Rev. Bul. No. 19, at 30, modifying Rev. Rul. 62-10, 1962-1 Cum. Buli.

305; Cox, Corporate Acquisitions, supra note 4, at 427 n.45.

103 Rev. Rul. 69-421, Pt. 2(h), 1969 INT. Rev. Bull. No. 32, at 10; Rev. Rul. 69-24, 1969 InT. Rev. Bull. No. 4, at 9, 10.

104 Treas. Reg. $\$ 1.401-1$ (b) (2), T.D. 6675, 1963-2 Cum. Bull. 151; Rev. Rul. $69-25, \S 2.02,1969$ INT. REv. BuLl. No. 4, at 14. The 1969 revenue rulings on termination retain the two concepts of "business necessity," introduced by Treas. Reg. 111, $\$ 29.165-1$ (a) (1943) and PS No. 52, Aug. 9, 1945, and "valid reason," introduced by Mim. 6136, 1947-1 Cum. Bulc. 58. However, a plan will presumably be regarded as permanent if either criterion can be met, a reasonable result in view of the fact that the terms overlap. See Cox, Amendments, supra note 7, at 1198-99; Goodman, Termination 52; Young, Miscellaneous Problems 694-95.

105 Rev. Rul. 69-25, § 3.02, 1969 Int. Rev. Burl. No. 4, at 14 ; see Seligman, Jr., supra note 10 , at 361 . 
ment's related "termination rule" 106 discussed above. ${ }^{107}$ Based upon the examples in a recent revenue ruling dealing specifically with terminations during the fourth and fifth years of a qualified plan, it would also appear that the termination of a qualified plan within six years after its effective date will clearly be subject to attack. ${ }^{108}$ Terminations occurring after the sixth, but before the tenth, year will probably be subject to attack, but on a somewhat less intense basis.

While the phrase "within a few years" has largely been ignored in official and unofficial commentaries, the terms "business necessity" and "valid business reason" have been discussed in several published materials. Such discussions indicate that business necessity or a valid business reason will be assumed under certain defined circumstances, many of which do not apply to corporate acquisitions. ${ }^{109}$ The relevant circumstances are as follows:

(A) Discontinuance of the employer's business. ${ }^{110}$

(B) Change in business ownership in an arm's length transaction. ${ }^{111}$

(C) Bona fide and substantial change in stockholdings and management. ${ }^{112}$

Pure stock acquisitions are clearly covered under category (C), regardless of the factors surrounding the acquisition ${ }^{113}$-i.e., whether

106 See Cox, Amendnents, supra note 7, at 1198.

107 See text accompanying notes 87-94 supra.

108 The examples in Rev. Rul. 69-24, 1969 Int. Rev. Buld. No. 4, at 9, 11-13, deal with the following time spans:

$\begin{array}{clc}\text { Example } & \text { Inception of Plan } & \text { Plan Termination Date } \\ \text { 1. } & \text { October 1, 1962 } & \text { January 31, 1967 } \\ \text { 2. } & \text { January 1, 1960 } & 1965 \\ \text { 3. } & \text { November, 1962 } & 1968 \\ \text { 4. } & \text { July 1, 1962 } & 1967\end{array}$

Time $S p a n$
$41 / 3$ years
Approx. 5 years
Approx. 6 years
Approx. 5 years

109 Rev. Rul. 69-24, 1969 INT. Rev. Bull. No. 4, at 9, 10; Rev. Rul. 69-25, §3, INr. REv. BuLL. No. 4, at 14, 15. Business necessity and valid business reasons include insolvency and bankruptcy (Rev. Rul. 69-24 and Rev. Rul. 69-25, § 3), the financial inability to continue a qualified plan (Rev. Rul. 69-24, Sit. 1 \& 4), and unfavorable business conditions not anticipated at the inception of a plan and not within the control of the employer corporation (Rev. Rul. 69-25, §3). The courts have expanded this list to include the failure to meet a plan's objectives, $\dot{K}_{\text {ane }}$ Chevrolet Co., 32 T.C. 596 (1959), gov't appeal dismissed nolle pros., 280 F.2d 423 (1st Cir. 1960), and an erroneous view of the government's policy with respect to deferred compensation plans, Ingram \& Co. v. Riddell, T.C. Civil No. 16831 (S.D. Cal., Nov. 29, 1955). See Young, Miscellaneous Problems, supra note 59, at 697-98, 700.

110 Rev. Rul. 69-25, § 3.03, 1969 Int. Rev. Buld. No. 4, at 14, 15.

111 Rev. Rul. 69-24, 1969 INT. Rev. Bull. No. 4, at 9, 10; Rev. Rul. 69-25, § 3.04, 1969 INT. Rev. Bull. No. 4, at 15.

112 Rev. Rul. 69-24, 1969 INr. Rev. Bull. No. 4, at 9, 10 ; Rev. Rul. 69-25, § 3.04, 1969 Int. Rev. Bull. No. 4, at 15.

113 Rev. Rul. 69-24, Sit. 2, 1969 Int. Rev. Bull. No. 4, at 11, involved the termination of $Y$ 's profit-sharing plan after $X$ corporation acquired the stock of, and liquidated $Y$ corporation. $X$ did not have its own profit-sharing or similar plan. Rev. Rul. 69-25, $\$ 3.04,1969$ INT. REV. BuLL. No. 4, at 15, discusses a stock acquisition, where the acquired corporation is retained as a subsidiary of the buyer and its qualified plan is terminated. The government's conclusion does not depend upon the existence or nonexistence of a buyer's plan. 
the acquired corporation is liquidated or retained as a subsidiary and whether the acquiring corporation has no plan or one plan for all employees, including those of any subsidiary corporation. However, the rulings do suggest that there must be some reason for termination of the acquired corporation's plan in addition to the mere fact of a change in stockholdings and management. ${ }^{114}$ For example, a plan may be terminated to prevent employee dissension in the event that the acquiring corporation has no plan, or to provide a uniform plan for all employees in the event that the acquiring corporation already has a separate plan.

Asset acquisitions would probably be covered under category (B) above, with any accompanying liquidation covered under category (A). Although the rulings give no examples, the caveat applicable to stock acquisitions presumably would also apply to asset acquisitions, requiring some reason for termination of the acquired corporation's plan, in addition to the mere fact of acquisition.

Mergers and consolidations probably fall within the ambit of the third category described above, although, again, there are no official examples which deal specifically with these transactions. Assuming that both transactions would be regarded as changes in stockholdings and management, the terminating corporation would probably be required to show a policy or people-oriented reason for termination of the acquired corporation's plan, as in the case of stock-for-stock and asset acquisitions. ${ }^{115}$

Three additional caveats are probably applicable to all corporate acquisitions. First, if the acquired corporation could have anticipated the actual acquisition and accompanying plan termination at the inception of its qualified plan, neither the acquired nor the acquiring corporation will be able to take advantage of the business necessity or valid business reason circumstances described above. ${ }^{116}$ Second, these special circumstances will not apply where the successor corporation was closely associated with the ownership or management of the acquired corporation. ${ }^{117}$

114 In Rev. Rul. 69-25, § 3.04, 1969 INT. REv. Bulc. No. 4, at 15, the government assumed that the acquiring corporation preferred to extend its own plan to employees of the acquired corporation, or to terminate the acquired corporation's plan, when the acquiring corporation had no plan of its own and the employees of both companies would be closely associated in their work. In Rev. Rul. 69-24, Sit. 2, 1969 INT. REv. Bunc. No. 4, at 11, the government assumed that continuation of the acquired corporation's plan after the corporate liquidation would cause dissension among employees, when the acquiring corporation did not have a plan of its own.

The examples in the rulings deal with the termination of a qualified plan by the successor corporation, but there would appear to be no reason to disregard the same qualifications in the case of a preclosing plan termination.

115 See Lurie, Pensions After Mergers, supra note 42, at 532.

116 Rev. Rul. 69-25, § 3.05, 1969 INT. Rev. Bull. No. 4, at 15.

117 Id. 
Finally, the burden of proving a valid business reason or business necessity will generally be greater where the termination results in discrimination in favor of the prohibited group, ${ }^{118}$ although the government has conversely indicated that in the case of a pension plan, the "termination rule" may eliminate or limit the additional evidence required to establish that the plan was intended as a permanent program for the benefit of employees in general. ${ }^{119}$ The significance of these provisions is not clear in the case of corporate acquisitions, where the government has given specific examples of those situations in which it will find a valid business reason or business necessity. Perhaps these provisions apply only to those situations which do not closely parallel the government's specific examples. ${ }^{120}$ Until the uncertainty is clarified, acquired corporations should be aware of possible difficulty with the government on the question of permanence in the event of discrimination on plan termination, and conversely, of a possible lack of difficulty in the absence thereof.

The acquired corporation should also be cognizant of the fact that the acquiring corporation may end up defending the issue of permanence in the event of a postclosing plan termination by the acquiring corporation, particularly in the case of " $A$ " and " $\mathrm{B}$ " type reorganizations. Unless it assumes all liability with respect to any unassessed taxes relating to disallowed section 404 deductions, the acquiring corporation will have little or nothing at stake in the defense. Therefore, the acquired corporation would be wise to insist upon a preacquisition termination of its qualified plan, if termination is the contemplated disposition.

\section{Separation From the Service}

Of primary concern to the key employees and shareholders of the acquired corporation will be the question whether they will be able to take advantage of the special long-term capital gain-"forward" averaging provisions of the Code ${ }^{121}$ in the event of plan termination with a resulting lump-sum distribution of their vested interests. If they cannot, the acquired corporation may favor continuation as opposed to termination, ${ }^{122}$ after considering the best alternatives to long-term

118 Rev. Rul. 69-25, §4.01, 1969 Int. Rev. Bul.. No. 4, at 15.

110 Rev. Rul. 69-25, $\$ \$ 4.03 \& 4.04,1969$ INT. Rev. BulL. No. 4, at 15-16.

120 See Rev. Rul. 69-25, §4.04, 1969 INT. Rev. Bull. No. 4, at 15-16.

121 Note 80 supra. The major portion of all lump-sum distributions from older qualified plans will, within the next few years, qualify for long-term capital gains treatment under $\$ 402(a)(2)$ of the Code. Thereafter, the tax advantages available under $\$ \$ 402$ (a) (2), 402(a) (5), \& 72(n) may or may not be significant. It is a matter of arithmetic.

122 See Qualified Retirement Plans-Capital Gain Distributions, supra note 6, at 8; Leydorf, "Separation from the Service" in Corporate Reorganizations, 46 TAXEs 627, 646 (1968) ; Wood, Pension Plans-Part I, supra note 10, at 24. 
capital gain and "forward" averaging-regular income averaging, ${ }^{123}$ the distribution of an annuity contract (with no available cash until normal retirement), ${ }^{124}$ or installment distributions over a number of years, possibly coupled with regular income averaging. ${ }^{125}$

Sections $402(a)(2), 402(a)(5)$, and $72(n)$ of the Code ${ }^{126}$ together provide that if the total distributions payable ${ }^{127}$ with respect to any employee are paid to a distributee within one taxable year (of the distributee) because of the employee's death or other separation from

${ }^{123}$ Qualified Retirement Plans-Capital Gain Distributions, supra note 6, at 8; Hanson, Getting capital gains on lump-sum payouts in the more umusual situations, 27 J. Taxation 158, 160 (1967); Nagel, Capital Gains Treatment for Employees on Lump-Sum Distribution from Qualified Pension and Profit-Sharing Plans, 43 TAXES 403, 406-07 (1965). that:

124 Treas. Reg. $\$ 1.402$ (a)-1(a) (2), T.D. 6676, 1963-2 Cum. Bull. 41, provides

If a trust described in section 401 (a) and exempt under section 501(a) purchases an annuity contract for an employee and distributes it to the employee in a year for which the trust is exempt, the contract containing a cash surrender value which may be available to an employee by surrendering the contract, such cash surrender value will not be considered income to the employee unless and until the contract is surrendered.

To qualify under this provision, all annuity contracts issued after 1962 must be nontransferable. Treas. Reg. $\$ 1.401-9$ (b) (1963). "If the contract distributed by such trust is a transferable annuity contract issued after $1962 \ldots$. then notwithstanding the preceding sentence the entire cash value of the contract is includible in the distributee's gross income, unless within such 60 days such contract is also made nontransferable." Treas. Reg. \$ 1.402(a)-1(a) (2), T.D. 6676, 1963-2 Cun. BuL. 41. Upon surrender of an annuity contract following the taxable year of distribution, the proceeds will not be taxable as long-term capital gain (at preferential rates). Rev. Rul. 55-298, 1955-1 Cum. Bull. 394; Rev. Rul. 65-268, 1965-2 Cum. Bull. 143; see Estate of George E. Russell, 47 T.C. 8 (1966). However, if an annuity contract and cash are distributed from an exempt trust within one taxable year of the distributee on account of "separation from the service," the cash will be taxable as longterm capital gain (at preferential rates), irrespective of the disposition of the annuity contract. Rev. Rul. 65-267, 1965-2 CuM. BuLL 141.

Treas. Reg. $\$ 1.402$ (a)-1(a)(2), T.D. 6676, 1963-2 CuMr. Bull. 41, does not grant favorable treatment to retirement income, endowment, or other life insurance contracts, unless

[W] ithin 60 days after the distribution of such contract, all or any portion of [the cash] value is irrevocably converted into a contract under which no part of any proceeds payable on death at any time would be excludable under section 101 (a) (relating to life insurance proceeds) ... [and] such contract is also made nontransferable.

See generally Mim. 6461, 1950-1 CUM. Bull. 73 \& PS No. 66, Nov. 10, 1950, both declared obsolete, Rev. Rul. 67-467, 1967-2 CUM. BuLL. 432; Rev. Rul. 60-84, 1960-1 CUM. Bull. 159; Joseph F. Lauinger, 22 T.C.M. 733 (1963), on remand from 281 F.2d 419 (2d Cir. 1960).

125 Qualified Retirement Plans-Capital Gain Distributions, supra note 6, at 8; Hoffman, Capital Gains Treatment of Distributions from Qualified Pension and ProfitSharing Plans, 40 TAxes 396, $396-98$ (1962) ; Nagel, supra note 123, at 407; Wood, Pension Plans-Part I, supra note 10 , at 25.

${ }^{126}$ INT. Rev. Code of 1954, $\$ 402$ (a) (2), 402(a) (5), \& $72(n)$; see note 80 supra. 127 INT. REv. CODE of 1954, $\$ 402$ (a) (3) (C) defines the term "total distributions payable" to mean:

[T] he balance to the credit of an employee which becomes payable to a distributee on account of the employee's death or other separation from the service, or on account of his death after separation from the service.

See Rev. Rul. 69-495, 1969 INT. REv. Bull. No. 38, at 10, stiperseding I.T. 3847, 1947-1 Cux. Bull. 65 \& PS No. 59, Feb. 25, 1947. 
the service, a portion of such distributions will be regarded as gain from the sale or exchange of a capital asset held for more than six months, while the balance in excess of any employee contributions (but only if attributable to an employee who had participated in the distributor plan for at least five taxable years) will be taxed essentially at the rate of seven times the increase in tax which would result from including $14 \%$ per cent of such balance in the distributee's gross income for the taxable year of receipt. These three sections apply only to distributions from a qualified deferred compensation plan. Therefore, long-term capital gains treatment and "forward" averaging will not be available in the case of discrimination on plan termination or in the event that the government is able successfully to establish that the plan was not from its inception a permanent program for the exclusive benefit of employees in general.

Assuming, however, that termination does not result in plan disqualification, the further question of "separation from the service" is raised. At the present time, there appear to be two approaches to the question-the Tax Court's view, as expressed in the now famous Gittens case, ${ }^{128}$ and the government's view, as expressed in its published and as yet unwithdrawn revenue rulings. ${ }^{129}$ The Tax Court has taken the position that separation from the service cannot occur in the case of a corporate reorganization or liquidation unless there is a substantial change in the make-up of employees of the acquired corporation. $^{130}$ In its view, separation will not occur when the change in

128 Victor S. Gittens, 49 T.C. 419 (1968).

129 Rev. Rul. 57-115, 1957-1 Cum. Bull. 160; Rev. Rul. 58-94, 1958-1 Cum. Bult. 194; Rev. Rul. 58-95, 1958-1 CuM. Bull. 197; Rev. Rul. 58-96, 1958-1 CuM. Bull. 200 ; Rev. Rul. 58-97, 1958-1 Cum. Buls. 201; Rev. Rul. 58-98, 1958-1 Cum. Bull. 202; Rev. Rul. 58-99, 1958-1 CuMr. Bull. 202; Rev. Rul. 58-383, 1958-2 Cum. Bull. 149; Rev. Rul. 63-22, 1963-1 Cum. Burx. 88; Rev. Rul. 65-147, 1965-1 Cum. BuLl. 180 ; see Qualified Retirement Plans-Capital Gain Distributions, supra note 6 , at 7 , indicating in effect that the National Office took a consistent position in the case of lump-sum distributions pursuant to the Ford-Philco reorganization, described in Victor S. Gittens, 49 T.C. 419 (1968).

${ }^{130}$ In the Gittens case, Philco-Penn established a qualified profit-sharing plan for salaried employees on December 31, 1943. On September 13, 1961, the company entered into a purchase and sale agreement with Ford, whereby Ford agreed to purchase its assets and assume its liabilities in exchange for common stock of Ford. On December 8, 1961, the profit-sharing plan was amended to define employer to mean Philco-Del after after September 13, 1961. (Philco-Del was the subsidiary established by Ford to take over the assets and liabilities of Philco-Penn.) By amendment, each participant was also given the right irrevocably to elect to receive, as of March 31, 1962, the benefits that he would have received under the plan had he then left the employ of Philco-Del. Finally, on December 11, 1961, the deal was closed. Taxpayer, an engineer specialist with Philco-Penn (and after the closing, with PhilcoDel) elected to receive his profit-sharing benefits in a lump sum. He did not actually leave the employ of Philco-Del until June 30, 1965. The Tax Court found no longterm capital gain, concluding that the distribution was on account of the reorganization, not on account of the taxpayer's separation from the service. Because the employees of Philco-Penn became employees of Philco-Del in the same capacities (with only two apparent changes in personnel-a new president and a new production manager), the reorganization did not result in an en masse separation from the service. 
employment relationship is merely formal or technical in nature-for example, when all employees of the acquired corporation become employees of the acquiring corporation, but perform the same job and, except for a few key personnel, remain generally unaware of any change in corporate ownership.

Under the Tax Court's rule, a substantial change in the make-up of employees would be unlikely either in the case of a mere change in stock ownership ${ }^{131}$ or in the case of mergers and consolidations. Similarly, assets transactions involving a mere change in corporate payrolls would also fall outside the category of a qualifying transaction. ${ }^{132}$ It is difficult, in fact, to determine under what circumstances the Tax Court would find a separation under its substantial change in make-up rule. Suppose, for example, that only the executives of the acquired corporation become employees of the acquiring corporation, but perform the same duties as division heads. Or suppose that all employees of the acquired corporation become employees of the acquiring corporation and that only fifty per cent of such employees (including the former executives of the acquired corporation) change jobs as a result of the transfer. In either case, will the executives be separated from the service of their former employer? The answer is not clear, and perhaps the only. certain separation under the Tax Court's view would be one in which all transferring employees take on new and different jobs.

To date the government has taken a somewhat different position than the Tax Court in its published rulings. For a separation to occur, the government maintains that there must be an actual termina-

There were two concurring opinions: Judge Tannenwald concluded that the distribution was on account of the taxpayer's election, rather than a separation from the service; Judge Featherston concluded that taxpayer had not separated from the service of the employer under the profit-sharing plan (Philco-Del) at the time of the distribution. For a discussion of the Gittens case see Leydorf, supra note 122, at 645-47; Tax Court obscures capital gain break on lump-sun plan payouts in reorganizations, 28 J. TAXation 332, 332-33 (1968); Wood, Pension Plans-Part II, supra note 52 , at 44 .

131 Maurice Osterman, 50 T.C. 970 (1968). The Tax Court does suggest, however, that if there is a change in corporate ownership, coupled with a radical change in business and a drastic reduction in the number of employees, there might be a separation from the service with respect to terminated employees.

132 United States v. Haggart, 410 F.2d 449 (8th Cir. 1969), rev'g 274 F. Supp. 817 (D.N.D. 1967); Victor S. Gittens, 49 T.C. 419 (1968). Although both Haggart and Maurice Osterman, 50 T.C. 970 (1968), involved inside or common corporate owners (in Haggart, taxpayer owned all outstanding shares of the acquiring corporation and constructively owned all shares of the acquired corporation; while in Osterman, taxpayer, an employee of corporation $X$, purchased $X$ 's oustanding stock), it would not appear that this factor alone would, under the Tax Court's view, mean no separation from the service. In such situations, if there were in fact a substantial change in the make-up of employees, the Tax Court would probably find long-term capital gain (subject, of course, to INT. REv. CoDE of 1954, $\$ 402$ (a) (5) ), unless the reorganization or acquisition device were used by shareholderemployees to generate a tax-favored distribution, in which case only the rank-and-file employees might have available to them the long-term capital gain-"forward" averaging provisions of the Code. 
tion of the employment relationship, a termination which cannot result from a purely formal or technical change in the ownership of a business. ${ }^{133}$ For example, the government suggests that there might be no separation from the service in the case of a merger or a " $\mathrm{B}$ " reorganization; ${ }^{134}$ conversely, the government has found separation from the service in the case of a " $C$ " reorganization, ${ }^{135}$ the sale of business assets for cash (either in fact or by application of the step transaction doctrine), ${ }^{136}$ and the sale of a division. ${ }^{137}$ However, the government has in effect taken a position almost identical to that of the Tax Court in the case of mere formal or technical changes in the ownership of a business. In Revenue Ruling 58-94, ${ }^{138}$ the government maintained that if qualified plan benefits are distributed on account of a corporate liquidation or reorganization rather than on account of an actual termination of the employment relationship, such benefits will be taxable at preferential rates only if the liquidation or reorganization involves a substantial change in the make-up of employees. ${ }^{139}$

133 See revenue rulings cited note 129 supra. For a brief review of the 1958 rulings see Leydorf, supra note 122, at 630-33; Wood, Pension Plans-Part I, supra note 10, at 22-23. See also United States v. Johnson, 331 F.2d 943, 949-51 (5th Cir. 1964), rev'g Civil No. 2498 (S.D. Ala., Jan. 3, 1963) ; Bushman, Jr. \& Buchanan, Separation from the Service, Tax Notes, 47 A.B.A.J. 831, 831-33 (1961); Scheff, silpra note 75, at 1062-63; Seligman, Jr., sipra note 10, at 364.

134 In Rev. Rul. 58-383, 1958-2 Cum. BuLl. 149, the government found separation from the service, where corporation $X$ acquired the assets, business, and employees of corporation $Y$, previously unrelated, by way of a " $\mathrm{B}$ " reorganization followed by a statutory merger under INT. REv. CODE of 1954, \$368(a) (1) (A). The government suggested that the result could have been different had the merger not been preceded by the " $B$ " reorganization. In Rev. Rul. 58-99, 1958-1 Cum. Butr. 202, the government found no separation from the service, where there was a mere change in stock ownership (as would occur in a "B" reorganization). Specifically, control of a subsidiary was transferred out of the hands of the parent corporation. See Rev. Rul. 58-95, 1958-1 Cun. BuLl. 197; Bushman, Jr. \& Buchanan, supra note 133, at 832 ; Scheff, supra note 75, at 1062-63; cf. TAX Managenent PorTfolto No. 92-2d, sipra note 22, at A-27, A-28; TAx MANAGEMrent MEMORANDUM No. 68-09, supra note 6, at 7; Robbins, supra note 4, at 970 .

135 Rev. Rul. 58-94, 1958-1 CuM. Bull. 194. Under the step transaction approach, the transactions described in Rev. Rul. 58-383, 1958-2 CuM. BuLl. 149 (a " $\mathrm{B}$ " reorganization followed by an "A" reorganization) were in effect regarded as a purchase of assets for stock under INT. REv. CoDE of 1954, \$368(a)(1)(C). See Taft, sipra note 4 , at $473-74$.

136 Rev. Rul. 58-95, 1958-1 Cum. Burl. 197 (involving a \$ 334(b) (2) liquidation) ; Rev. Rul. 58-96, 1958-1 CuM. BuLL. 200 (involving a sale of assets for cash).

137 Rev. Rul. 58-97, 1958-1 CuMr. BuLL. 201.

138 Rev. Rul. 58-94, 1958-1 Cun. Buzl. 194.

[T] he phrase 'separation from the service' in section 402 (a) (2) of the Code as finally enacted does not extend to distributions resulting from the liquidation or reorganization of a corporate employer, which do not involve a substantial change in the make-up of employees, except as section $402(\mathrm{e})$ of the Code requires such distributions to be considered on account of separation from service for the limited period to which that subsection is applicable. 1958-1 Cum. Bull. at 195.

139 The government's position appears to be unaffected by whether or not an employee claiming preferred tax treatment continues to perform the same services for the acquiring or successor corporation. All of the 1958 rulings were premised upon a continuing employment relationship. See also Rev. Rul. 63-22, 1963-1 CuM. BuLL. 88; Precedential Effect of Funkhauser Case on Rulings, Tax Managenent Menro- 
Left unanswered is the question whether the government's or the Tax Court's definition of separation from the service will prevail. The answer should depend in large measure on relevant legislative history, which centers around section $402(\mathrm{e})$ of the Code. ${ }^{140}$ Section $402(\mathrm{e})$ provides that for purposes of section 402(a) (2), distributions made during 1954 as a result of the complete termination of a qualified deferred compensation plan, incident to the complete liquidation of the corporate employer prior to enactment of the 1954 Code, shall be regarded as distributions on account of separation from the service. Section 402(e) represents a modification of the House version of section 402(a) (2), which would have allowed long-term capital gains treatment in the case of all corporate liquidations, including statutory mergers. ${ }^{141}$ In adding section $402(\mathrm{e})$, the Senate Finance Committee noted:

The House bill extends capital gains treatment to lumpsum distributions to employees at the termination of a plan because of a complete liquidation of the business of the employer, such as a statutory merger, even though there is no separation from service. This was intended to cover, for example, the situation arising when a firm with a pension plan merges with another firm without a plan, and in the merger the pension plan of the first corporation is terminated.

RANDUM No. 67-14, 10-11 (July 3, 1967). For a general discussion of the impact of continuing employment in a nonreorganization context on the question of long-term capital gain see Special Ruling, Dec. 22, 1960, John W. S. Littleton, Director, Tax Rulings Division, Internal Revenue Service, 2 P-H PEN. \& Pro. Srarrng $\Uparrow 11,981$; Rev. Rul. 69-647, 1969 Int. Rev. Bull. No. 52, at 12; Barrus v. United States, Civil No. 674 (E.D.N.C. Feb. 24, 1969); Retention of Key Pensioned Ex-employee as Consultant, Tax Management Memorandum No. 67-08, at 9 (April 10, 1967); Bushman. Jr. \& Buchanan, supra note 133, at 832-33; Goodman, How to obtain capital gain treatment on distributions from qualified plans, $24 \mathrm{~J}$. TAXATION 76, 77-78 (1966); Nagel, supra note 123, at 404; Points to Remember 12, 21 TAX LAw. 246 (1967); Scheff, supra note 75, at 1061-62.

The government's position will, however, be affected by whether or not the principals of the acquiring corporation were owners or managers of the acquired corporation, when such a relationship could mean a mere formal or technical change in the ownership of the business. In Rev. Rul. 58-383, 1958-2 Cum. Bul.. 149, for example, the government noted that the acquired and acquiring corporations were unrelated. See note 134 supra. In Rev. Rul. 58-97, 1958-1 Cum. BuLL. 201, involving the sale of a division, the government noted that the selling corporation did not control and was not controlled by the purchasing corporation. In Rev. Rul. 65-147, 1965-1 CUM. BuLl. 180, the government found long-term capital gain, when corporation $X$ sold substantially all of its assets to corporation $Z$, which in turn transferred these assets to corporation $Y$ by way of a statutory merger. Prior to the merger, the officers and shareholders of corporation $X$ were identical to those of corporation $Y$. However, corporation $X$ was engaged in the shirt business, while corporation $Y$ was an operating real estate company. The government noted that the common ownership of $X$ and $Y$ was "not such a relationship of companies that would prevent the officers and clerical personnel employed by $Y$ from being 'separated from the service' of $X$ " under INr. Rev. Code of 1954, $\$ 402(\mathrm{a})(2)$ and Rev. Rul. 58-383, 1958-2 Cun. Bull. 149. 1965-1 CuM. Bull. at 180.

140 INT. Rev. Code of 1954, $\$ 402$ (e).

141 H.R. REP. No. 1337, 83d Cong., 2d Sess. A147 (1954) ; see Victor S. Gittens, 49 T.C. 419 , at 427-28 (1968); Rev. Rul. 58-94, 1958-1 Cun. Bull. 194. 
Your committee's bill revises this provision of the House bill to eliminate the possibility that reorganizations which do not involve a substantial change in the make-up of employees might be arranged merely to take advantage of the capital gains provisions. Thus, your committee's bill would grant capital gains treatment to lump-sum distributions occurring in calendar year 1954 where the termination of the plan is due to corporate liquidation in a prior calendar year... to avoid hardship. ${ }^{142}$

An analysis of this legislative history suggests that the government's interpretation of the phrase "separation from the service" is correct. The Senate did not wish to authorize special tax treatment of lump-sum distributions from qualified plans in the case of mere technical changes in the ownership of a business, such as mergers or the liquidation of a subsidiary into its parent corporation, absent the showing of a substantial change in the make-up of employees. ${ }^{143}$ No suggestion was made in the Senate, however, that asset transfers and "C" reorganizations required anything more than evidence of an actual termination of the employment relationship.

The government's position is consistent not only with the legislative history but also with a long line of cases ${ }^{144}$ authorizing preferential tax treatment in asset sales ${ }^{145}$ and finding no separation from the service in the case of stock acquisitions. ${ }^{146}$ On the other hand,

142 S. Rep. No. 1622, 83d Cong., 2d Sess. 54 (1954); see id. 289-90; H.R. Rep. No. 2543, 83d Cong., $2 d$ Sess. 42 (1954).

143 See Victor S. Gittens, 49 T.C. 419, at 428 (1968) (Tannenwald, J., concurring); Lurie, Pensions After Mergers, snpra note 42, at 533-34.

144 For a general survey of the relevant cases see Leydorf, supra note 122, at $633-45$.

145 Greenwald v. Commissioner, 366 F.2d 538 (2d Cir. 1966), aff'g in part \& rev'g in part 44 T.C. 137 (1965) (involving a sale of assets, presumably for cash); Lester B. Martin, 26 T.C. 100 (1956), acquiesced in, 1958-1 CuM. BuLL. 5 (involving a purchase of stock, followed $6 \mathrm{t} / 2$ months later by a corporate liquidation); Mary Miller, 22 T.C. 293 (1954), aff'd, 226 F.2d 618 (6th Cir. 1955) (per curiam), not acquiesced in, 1955-1 Cum. Bull. 8, acquiesced in, 1958-1 Cum. BulL. 5 (involving a transfer of assets for common stock); see Jack E. Schlegel, 46 T.C. 706 (1966) (involving the purchase by corporation $X$ of all the shares of corporation $Y$, the liquidation of corporation $Y$ into corporation $X$, and the termination of $Y$ 's profitsharing plan several months later). One additional significant factor was involved in both Miller and Martin-participating employees were eligible to receive the same amount upon a plan termination as upon termination of their employment. The court specifically noted in Miller that:

The situation is therefore one where petitioners' rights to receive distributions of their shares of the fund arose "on account of" their separation from the service of their employer, but the actual equivalent distribution of those shares was made in the course of terminating the fund.

22 T.C. at 301.

146 McGowan v. United States, 277 F.2d 613 (7th Cir. 1960), aff'g 175 F. Supp. 364 (E.D. Wis. 1959) (involving a taxpayer who ceased to be a member of The Savings \& Profit Sharing Pension Fund of Sears, Roebuck, when his employer ceased to be a wholly owned subsidiary of Sears) ; Beecher v. United States, $226 \mathrm{~F}$. Supp. 547 (N.D. Ill. 1963) (involving the termination of a subsidiary's plan preceding dissolution of the corporation); Nelson v. United States, 222 F. Supp. 712 (D. Idaho 1963) (involving the pension plan of Liberty National Insurance Company, a corporation 
suggestions of the Gittens view are evident in at least three prior cases, two decided by the Tax Court ${ }^{147}$ and the third, United States $v$. Johnson, ${ }^{148}$ decided by the United States Court of Appeals for the Fifth Circuit, in which the court noted that:

[A]fter 1954 a separation from service would occur only on [an] employee's death, retirement, resignation, or discharge; not when he continues on the same job for a different employer as a result of a liquidation, merger or consolidation of his former employer. ${ }^{149}$

For the acquired corporation, the only solution to the interpretative dilemma created by Gittens would appear to be a private ruling, regardless of whether the given circumstances are similar to those described in one of the government's several published rulings. ${ }^{150}$ The corpora-

"rehabilitated" through a receivership) ; Jacob v. Donnelly, 218 F. Supp. 845 (E.D. La. 1963), vacated \& remanded, No. 20945 (5th Cir., Mar. 3, 1964), affd, 374 F.2d 503 (5th Cir. 1967) (per curiam) (involving the Paramount-Richards Theatres, Inc. antitrust proceedings); William S. Bolden, 39 T.C. 829 (1963) (involving the sale of stock in a corporation in which the key employee stayed on as an advisor and consultant) ; Harry K. Oliphint, 24 T.C. 744 (1955), aff'd on other groutuds, 234 F.2d 699 (5th Cir. 1956) (per curiam) (involving a change in ownership of ParamountRichards Theatres, Inc.); Robert L. Tedeschi, 25 CCH Tax Ct. Mem. 1205 (1966) (involving the acquisition by Stop \& Shop, Inc. of $100 \%$ of the stock of the sole shareholder of a small supermarket); Robert E. Beaulieu, $24 \mathrm{CCH}$ Tax Ct. Mem. 1670 (1965) (involving the termination of two qualified plans after $80 \%$, but before $100 \%$, of the corporate shares changed hands). There are four additional cases which involve the purchase by corporation L, on May 5, 1955, of over $99 \%$ of the common stock of Waterman Steamship Corp., the termination of Waterman's pension plan on said date, a lump-sum payment to participating employees on August 1, 1955, and the merger of corporation $L$ into Waterman pursuant to an agreement dated November 16, 1955; United States v. Martin, 337 F.2d 171 (8th Cir. 1964), rev'g 229 F. Supp. 549 (D). Minn. 1963) (where taxpayer did not leave the employ of Waterman); United States v. Johnson, 331 F.2d 943 (5th Cir. 1964), rev'g Civil No. 2498 (S.D. Ala., Jan. 3, 1963) (where taxpayer did not leave the employ of Waterman) ; United States v. Peebles, 331 F.2d 955 (5th Cir. 1964), rev'g. 208 F. Supp. 385 (S.D. Ala. 1962); Thomas E. Judkins, 31 T.C. 1022 (1959), acquiesced in, 1959-2 CuM. BuLL. 5, not acquiesced in, 1963-2 Cum. Bull. 6 (where taxpayer did in fact leave the employ of Waterman on June 1,1955 ).

147 Thomas E. Judkins, 31 T.C. 1022 (1959), acquiesced in, 1959-2 Cum. Bulc. 5, not acquiesced in, 1963-2 Cunr. Buld. 6; Robert E. Beaulieu, $24 \mathrm{CCH}$ Tax Ct. Mem. 1670 (1965). The court noted in Judkins that certain statements in the Committee Reports on $\$ 402$ of the Revenue Act of 1954 "inferentially cast some doubt on the applicability of the capital gains treatment to distributions made upon termination of [deferred compensation] plans incident to and as a result of corporate reorganizations wherein there was an actual change of ownership of the business, as existed in the Miller and Martin cases . . ." 31 T.C. at 1028; see note 145 stipra. In Beauliet, the court used substantial change in employee make-up language, noting that there was only a minor shift in personnel.

148331 F.2d 943 (5th Cir. 1964), rev'g Civil No. 2498 (S.D. Ala., Jan. 3, 1963). $149 \mathrm{Id}$. at 949 . The court continued:

In spite of Section $402(\mathrm{e})$, the Internal Revenue Service has ruled that distributions on termination of a plan incident to a liquidation or reorganization of a corporation after 1954 will qualify for capital gains treatment under Section 402 (a) (2), if the distributions were made on account of "separation from the service."

Id.; see Leydorf, supra note 122, at 636.

150 See Tax Court obscures capital gain break on lump-sunn plan payouts in reorganizations, supra note 130 , at 333 . Tax Management indicates, however, that 
tion should, however, take at least two other precautionary measures. First, if a qualified plan is to be terminated, it should be terminated by the acquired corporation, rather than by the acquiring corporation after a brief assumption of all plan obligations; for with respect to employees who continue with the acquiring corporation, there could, under the latter circumstances, be no separation from the service of their employer. ${ }^{151}$ Second, if a plan is to be terminated, participating employees should not be given an unrestricted election regarding an immediate, as opposed to deferred, distribution of their benefits, for it could be argued that any immediate distribution was on account of the election rather than on account of separation from the service. ${ }^{152}$ The acquired corporation in the Gittens case failed to take either of these precautionary measures: the acquiring corporation became the employer under the acquired corporation's qualified plan, and employees were given an election regarding the distribution of their benefits. It seems significant that both factors could have formed the basis of the majority opinion of the Tax Court.

\section{In What Manner Should the Seller's Plan Be Continued?-The Buyer's PoINT OF View}

The buyer may decide to continue the seller's plan for any number of reasons. From a purely employee-oriented policy point of view, continuation may be the better alternative; or, in the case of an extremely attractive acquisition, continuation may be the only alternative acceptable to the selling corporation. There may also be unused profitsharing contribution carryovers available only to the employer under a continuing plan; unused deduction carryovers of far more value in the context of a continuing plan; or significant overfunding under the seller's qualified pension plan, which could reduce the buyer's future deferred compensation costs.

Having decided to continue the seller's plan, the buyer must determine the best mode of continuation, although the questions whether to continue and how to continue the seller's plan are not mutually exclusive

the capital gains-acquisition area is under review by the Service, and that private rulings will probably be unavailable until the review has been completed. TAX MANAGEMENT MEMTORANDUM No. 68-09, supra note 6 , at 8 . ,

151 See Funkhauser v. Commissioner, 375 F.2d 1 (4th Cir. 1967), aff'g 44 T.C. 178 (1965) ; Rybacki v. Conley, 340 F.2d 944 (2d Cir. 1965), aff'g Civil Nos. 9314, 9315, 9372 (D. Conn., Nov. 22, 1963); Clarence F. Buckley, 29 T.C. 455 (1957), annetzded, $17 \mathrm{CCH}$ Tax Ct. Mem. 837 (1958); Edward Joseph Glinske, Jr., 17 T.C. 562 (1951); Jack E. Schlegel, 46 T.C. 706 (1966); B. Fox \& E. Fox, supra note 4, at $\$ 5.06$ [3] ; Leydorf, supra note 122, at 627 (editor's footnote); Tax Court obscures capital gain break on lump-sum plan payouts in reorganizations, supra note 130 , at 333 .

152 See Victor S. Gittens, 49 T.C. 419, 427 (1968) (Tannenwald, J., concurring). For a discussion of additional precautionary measures see $\mathrm{B}$. Fox \& E. Fox, supra note 4, at $\$ 5.06[3]$; Cox, Amendments, supra note 7, at 1221; Goodman, Termination, supra note 87 , at 56 . 
and as a practical matter would be considered simultaneously. There are three alternative forms of continuation: the seller's plan could be continued on an inactive basis, or as a separate, active plan, or as a part of the buyer's existing deferred compensation plan. The choice should to a large extent depend upon the buyer's reasons for choosing to continue, rather than to terminate, the seller's plan.

\section{A. Inactive Plan}

If the buyer chooses plan continuation only to satisfy the seller's concerns regarding discrimination upon termination and separation from the service, the best form of continuation would probably be continuation on an inactive basis until all participating employees have attained their retirement age or left the employ of the acquiring corporation. ${ }^{153}$ In order to accomplish this objective, a preclosing amendment would be required, under which any premature distribution provisions would be deleted and under which the buyer might be designated as successor employer. ${ }^{154}$ The amendment might also provide that no employees could join the plan after the effective date of the amendment, although they might otherwise satisfy the requirements for eligibility.

Continuation of the seller's plan on an inactive basis should not result in a loss of qualified status. The applicable law ${ }^{155}$ requires full vesting in the case of a complete suspension or discontinuance of contributions to a qualified pension or profit-sharing plan..$^{156}$ However, the rulings do not indicate that the government will automatically withdraw its prior qualification, either on a retroactive or a current basis, ${ }^{157}$

153 For a general discussion of the circumstances under which an inactive plan might be the better alternative see TAX MANAGEMENT PoRTFoLIo No. 92-2d, supra note 22, at A-33; Cox Amendments, supra note 7, at 1185 n.12; Nagel, supra note 123, at 405-06.

If "separation from the service" is of primary concern to the acquired corporation, however, the choice of an inactive plan would be advisable (from the acquired corporation's point of view) only if the acquired corporation could be reasonably certain that transferred employees would not be regarded as separated from the service of the acquired corporation-otherwise capital gains treatment (as limited by INT. REv. CODE of 1954, § 402(a) (5)) might be unavailable upon the ultimate distribution of benefits in a lump-sum. Arguably, distribution would be on account of plan continuation, rather than on account of separation from the service, as required by INT. REv. CODE of $1954, \S 402$ (a) (2). Alternatively, all amounts accrued after the acquisition might represent ordinary income under Rev. Rul. 60-292, 1960-2 CuM. BuLL. 153. See TAX Management Mearoranduar No. 68-09, supra note 6, at 3; Hanson, supra note 123, at 160.

154 See Cox, Amendments, supra note 7, at 1185 n.12; Robbins, supra note 4, at 954. 155 Treas. Reg. $\$ 1.401-6$ (a) (1) (1963); Rev. Rul. 69-421, Pt. 6(d), 1969 INT. Rev. Bull. No. 32, at 35-36; Rev. Rul. 55-186, 1955-1 CuM. Bulz. 39, modified, Rev. Rul. 56-596, 1956-2 Cum. BuLc. 288; see Cox, Amendments, supra note 7, at 1205. 156 The phrase "complete discontinuance of contributions under the plan" is defined in Treas. Reg. $\$ 1.401-6$ (c) (1963).

157 Rev. Rul. 55-186, 1955-1 Cum. Bulc. 39 \& PS No. 57, Aug. 5, 1946, modified, Rev. Rul. 56-596, 1956-2 Cux. BuLl. 288; see Lurie, Plastic Contributions, supra note 11, at 1021 . 
although a retroactive withdrawal would theoretically be possible if the government could establish impermanence.

A recently published revenue ruling ${ }^{158}$ also provides that any trust established under a qualified plan will remain tax exempt if the plan is retained on an inactive and qualified basis until all employees have received their fully vested interests at retirement age or earlier, in accordance with the terms of the plan. Thus, the vested accounts of participating employees under the seller's inactive plan could accumulate interest on a tax-free basis.

From the buyer's point of view, there would appear to be only one possible disadvantage to the inactive plan approach-full vesting would eliminate the benefit of any overfunding and the availability of forfeitures. ${ }^{159}$

\section{B. Separate Plan}

\section{Continuing Qualification}

If the buyer wishes to continue the seller's plan on a separate basis, perhaps because the seller's business will be operated as a division of the acquiring corporation, or because the selling corporation will remain intact as a subsidiary of the buyer, or because the buyer wishes to use the seller's plan as a basis for its company-wide deferred compensation program, the buyer must first determine whether the seller's plan can be continued separately on a qualified basis. Disqualification will be unlikely if the selling corporation becomes a subsidiary of the buyer, assuming there is no radical shift in the make-up of the seller's personnel. However, the buyer may find it difficult to establish continuing qualification if the seller's plan is placed in a totally new environment. The problem is essentially one of coverage. ${ }^{160}$

Section 401(a) (3) of the Code provides that a qualified plan must provide benefits for seventy per cent or more of all employees of the employer (or eighty per cent of all eligible employees, if seventy per cent or more of all employees are eligible for benefits), excluding

158 Rev. Rul. 69-157, 1969 INr. Rev. Bull. No. 14, at 13. Prior to the publication of this ruling, there was much speculation regarding the availability of the inactive plan alternative, and it was commonly thought that there could be a tax exempt "trust" without a continuing, active "plan." See Alexander, Tax Status of Pension Trtusts: Requirements for Maintaining Exemption, N.Y.U. 13TH INST. ON FED. TAX. 435, 445 (1955); Cox, Amendments, supra note 7, at 1184-85; Nagel, supra note 123, at 405 ; Robbins, supra note 4 , at $963-64$.

${ }^{159} \mathrm{It}$ is unlikely that any otherwise available carryover deductions would be available on only a restricted basis under Treas. Reg. $\$ 1.404$ (a) -7 (b) and Treas. Reg. $\$ \$ 1.404$ (a) -9 (b) (2) \& (e) (2), T.D. 6534, 1961-1 CUM. BULL. 145. The restrictions thereunder apparently apply only in the case of an actual plan termination, except as provided in the regulations under INT. REv. CODE OF 1954, \$ 381 (c) (11).

Ie0 See Goodman, Reorganizations, supra note 21, at 167; Lurie, Pensions After Mergers, stpra note 42, at 535-36. 
in both cases certain part-time, temporary, and seasonal employees, and those employees who have not been on the employer's payroll for up to five full years, as defined in the governing instrument. ${ }^{161}$ Alternatively, section 401 (a) (3) provides that a qualified plan must provide benefits for a nondiscriminatory group of employees. Specifically, the classification of covered employees must not "be discriminatory in favor of employees who are officers, shareholders, persons whose principal duties consist in supervising the work of other employees, or highly compensated employees." 162

If the seller's plan is not used as the basis for a company-wide deferred compensation program, it is unlikely that the plan will in and of itself meet the percentage coverage requirements of section 401 (a) (3), although the acquiring corporation may have other plans which when combined with the seller's plan would together satisfy the seventy or eighty per cent requirements of the Code. ${ }^{163}$ If not, the acquiring corporation must establish that the seller's plan does not discriminate in favor of the prohibited group, whose members may be difficult to identify. The term "officer," for example, does not include an officer-employee who performs only nominal duties in a substitute capacity, such as an assistant clerk or an assistant secretary. ${ }^{164}$ Nor does the term "shareholder" include an individual who owns only a few shares of stock in a large corporation. ${ }^{165}$ Similarly, supervisory em-

161 INT. REv. CoDE of 1954, $\$ 401$ (a) (3) (A) provides that a deferred compensation plan will meet the coverage requirements of the Code if :

70 percent or more of all the employees, or 80 percent or more of all the employees who are eligible to benefit under the plan if 70 percent or more of all the employees are eligible to benefit under the plan, excluding in each case employees who have been employed not more than a minimum period prescribed by the plan, not exceeding 5 years, employees whose customary employment is for not more than 20 hours in any one week, and employees whose customary employment is for not more than 5 months in any calendar year . . . .

See H.R. Rep. No. 2333, 77th Cong., 2d Sess. 103-04 (1942) ; S. Rep. No. 1631, 77th Cong., 2d Sess. 136-37 (1942).

162 INT. REv. Code of 1954, §401(a) (3) (B); see H.R. REP. No. 2333, 77th Cong., 2d Sess. 104 (1942); S. REP. No. 1631, 77th Cong., 2d Sess. 137 (1942).

163 INT. REV. CODE OF 1954, $\$ 401$ (a) (3) permits a combination of plans. The regulations provide that:

An employer may designate several trusts or a trust or trusts and an annuity plan or plans as constituting one plan which is intended to qualify under section 401 (a) (3), in which case all of such trusts and plans taken as a whole may meet the requirements of such section.

Treas. Reg. §1.401-3(f) (1956) ; see Rev. Rul. 69-421, Pt. 4(a), 1969 INr. Rev. Buls. No. 32, at 21; Goodman, Reorganizations, supra note 21 , at 168 . However, the benefits or contributions under all trusts must be nondiscriminatory. See INT. REv. CoDE of 1954, \& 401 (a) (4); S. REP. No. 1631, 77th Cong., 2d Sess. 137 (1942); Rev. Rul. 66-15, 1966-1 CuM. BuLI. 83; PS No. 27, Sept. 2, 1944.

164 Rev. Rul. 68-300, 1968-1 CUM. Bull. 159, superseding PS No. 4, July 29, 1944 (an officer is an administrative executive who is in regular and continued service); see Gordon, supra note 11 , at 1156.

165 See Pension or Profit-Sharing Plans (Salaried Only)-Recent Developments, Tax Management MeMorandum No. 68-17, at 3 (Aug. 12, 1968); Gordon, supra note 11 , at $1154-55$. 
ployees must spend at least fifty per cent of their time directly supervising the work of other employees of the employer, ${ }^{106}$ so that employees who spend all of their time drafting plans and schedules or who spend only forty per cent of their time in direct employee supervision could not be regarded as supervisory within the meaning of section 401 (a) (3).

The most troublesome term is "highly compensated," which has been defined by the government to mean highly compensated in relation to other employees of the employer. ${ }^{167}$ Under this definition, if the salaries or wages paid by company $X$ ranged between $\$ 1,000$ and $\$ 5,100$ a year, those earning $\$ 5,000$ would be regarded as highly paid, unless a substantial number of employees fell within the $\$ 5,000$ category. Such an approach has been accepted by the United States Court of Appeals for the Second Circuit, although the Tax Court and the United States District Court for the Northern District of New York had previously adopted different definitions. The Tax Court would relate the term highly compensated to standards that might produce substantial tax avoidance, ${ }^{168}$ while the district court would compare the compensation of any particular employee with the compensation of other employees in today's economy. ${ }^{169}$ Both approaches have merit, but neither can form a basis for reliable tax planning. . $^{170}$

The acquiring corporation must demonstrate on the basis of government approved definitions that the seller's plan is nondiscriminatory within the meaning of section 401 (a) (3) of the Code. If the acquiring corporation has only a union plan, and if the seller's plan covers only salaried employees, the problem is perhaps more difficult.

There are generally four approaches available to the buyer who wishes to establish that the seller's plan does not violate the non-

106 See Pepsi-Cola Niagara Bottling Corp., 48 T.C. 75 (1967), rev'd on other grounds, 399 F.2d 390 (2d Cir. 1968) ; Gordon, supra note 11, at 1156-57.

167 Rev. Rul. 69-398, 1969 INT. Rev. Bul.. No. 29, at 8, based upon Commissioner v. Pepsi-Cola Niagara Bottling Corp., 399 F.2d 390 (2d Cir. 1968), rev'g 48 T.C. 75 (1967) ; Rev. Rul. 56-497, 1956-2 CUM. BuLr. 284; see Young, Salaried-Only Plans, supra note 97, at 820 . For purposes of determining whether certain salaried employees are highly paid, the compensation of hourly paid employees may not include required contributions to various welfare benefit plans. See Rev. Rul. 66-15, 1966-1 CuM. BuLL. 83; Scheff, supra note 75, at 1032.

168 Pepsi-Cola Niagara Bottling Corp., 48 T.C. 75 (1967), rev'd, 399 F.2d 390 (2d Cir. 1968) ; Ray Cleaners, Inc., 27 T.C.M. 23 (1968) ; see Gordon, supra note 11, at 1157-58; Young, Salaried-Only Plans, supra note 97, at 819-20.

169 John Duguid \& Sons, Inc. v. United States, 278 F. Supp. 101, 105 (N.D.N.Y. 1967) ; see Young, Miscellaneous Problems, supra note 97, at 704-05.

${ }^{170}$ The Second Circuit made the following comment in Commissioner v. PepsiCola Niagara Bottling Corp., 399 F.2d 390, 393 (2d Cir. 1968), rev'g 48 T.C. 75 (1967) :

When Congress has used a general term and has empowered an administrator to define it, the courts must respect his construction if this is within the range of reason. . . That requirement was met here and it was not for the Tax Court to substitute its reading for that of the administrator on the firing line. 
discriminatory coverage requirements of the Code, although the plan excludes union employees and covers some top level executives and clearly supervisory personnel, i.e., members of the prohibited group. First, the acquiring corporation may argue that the seller's plan is nondiscriminatory because it covers a "fair cross section" of corporate employees - that is, a substantial number of employees in the low, middle, and top income brackets ${ }^{171}$-many of whom are not officers, shareholders, or supervisors within the meaning of the Code.

Second, if the seller's plan is integrated with Social Security at the $\$ 7,800$ level, the acquiring corporation might argue that all excluded union employees are already covered under Social Security and that those union employees who would be eligible to participate in the seller's plan were it not for the salaried-only requirement earn more than many salaried employees excluded from the plan because their compensation does not exceed the required $\$ 7,800$ per year. ${ }^{172}$

A third approach, the one most applicable to the construction and other seasonal industries, is the argument that most, if not all, union employees are temporary or seasonal employees, hired on a day-to-day or on a per job basis. For purposes of the nondiscrimination requirements of section 401(a) (3), there would appear to be no reason why such employees should be included among the list of ineligibles, particularly when the exclusion of temporary and seasonal employees is sanctioned under the percentage coverage requirements of section 401 (a) (3)..$^{173}$

The fourth approach is that of comparability, under which the acquiring corporation might argue that because the benefits available under the union's qualified deferred compensation plan are comparable to those provided under the seller's salaried-only plan, there is in fact no discrimination. ${ }^{174}$ Comparability is difficult to establish, particu-

171 See Goodman, Coverage Under Pension and Profit-Sharing Plans, speech delivered at the 16th Annual Midyear Conference of the Tax Executives Institute, Washington, D.C., Mar. 24, 1966, 3 CCH PEN. PLAN GUIDE \28,700, \28,704; Pension or Profit-Sharing Plans (Salaried Only)-Recent Developinents, supra note 165, at 3. See generally Dederick, supra note 93, at 272; Goodman, Establishing a Tax-Qualified Pension, Annuity, Profit-Sharing or Stock Bonns Plan, speech delivered to Central Arkansas Estate Council, Little Rock, Ark., Oct. 26, 1961, 3 CCH PEN.

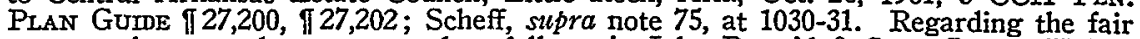
cross section test, the court noted as follows in John Duguid \& Sons, Inc. v. United States, 278 F. Supp. 101, 105 (N.D.N.Y. 1967):

I would think that some rule of thumb, common sense guide and standard must necessarily evolve on the administrative level to effectuate the statutory purposes.

172 See Tax Management Memorandum No. 68-17, sipra note 165, at 9.

173 See John Duguid \& Sons, Inc. v. United States, 278 F. Supp. 101 (N.D.N.Y. 1967) ; Ed \& Jim Fleitz, Inc., 50 T.C. 384 (1968). It is likely, however, that a plan would also qualify under the percentage requirements of $\$ 401$ (a) (3) if most hourly paid (construction) workers were hired on a day-to-day basis.

174 See Loper Sheet Metal, Inc., 53 T.C. No. 38 (Dec. 8, 1969) ; Rev. Rul. 66-15, 1966-1 Cum. Bull. 83; PS No. 27, Sept. 2, 1944. Under the comparability approach, 
larly when the seller's plan is a profit-sharing plan. In the case of a union pension plan and a nonunion profit-sharing plan, the government has taken the position that the annual contribution to each plan, expressed as a percentage of compensation, must be equal. ${ }^{175} \mathrm{~A}$ comparison of benefits presumably will be made only in the case of two pension plans, or in the case of a union pension plan and a nonunion profit-sharing plan that pass the initial contribution equivalence hurdle. ${ }^{176}$

Problems of discrimination may exist in situations other than those in which the acquiring corporation has a separate plan for its union employees and the seller's plan covers only salaried personnel. The seller's plan, for example, may cover all salaried and hourly paid employees of the selling corporation, which becomes a division of the buyer, and the buyer may have a separate plan or no plan for its nondivision employees. ${ }^{177}$ The analysis is similar, although the circumstances may differ. ${ }^{178}$

\section{Curtailment}

If the acquiring corporation decides to continue the seller's qualified plan on a separate basis, but at the same time decides to modify the plan in certain respects by way of amendment, the corporation may have a curtailment on its hands. Curtailment will generally occur when benefits are reduced, when employee contributions are introduced with no corresponding increase in benefits, when the vesting schedule is expanded in length of years, or when the eligibility requirements become more restrictive. ${ }^{178}$

The consequences of a curtailment will be particularly unpalatable to the acquiring corporation that chooses plan continuation due either to the available carryovers ${ }^{180}$ or to significant overfunding. First, full

the question of discrimination will generally arise under $\$ 401$ (a) (4) of the Code, rather than under $\$ 401(a)(3)(B)$-for the percentage coverage requirements of $\$ 401$ (a) (3) (A) will generally be met. Section 401 (a) (4) provides that the contributions or benefits provided under a qualified plan cannot discriminate in favor of the prohibited group.

175 See Rev. Rul. 66-15, 1966-1 CuM. Burc. 83.

176 For an unacceptable approach in the union area see Rev. Rul. 66-14, 1966-1 CuMr. BuLc. 75.

177 For a list of available classifications see Treas. Reg. $\$ 1.401-3$ (d) (1956); Rev. Rul. 69-421, Pt. 4(c), 1969 Int. Rev. BuLL. No. 32, at 22.

178 See generally Rev. Rul. 66-12, 1966-1 CuMr. Bunc. 72; Rev. Rul. 66-13, 1966-1 Cuns. BuLs. 73.

179 Rev. Rul. 69-24, 1969 INt. Rev. Bull. No. 4, at 9, 10-11; see Rev. Rul. 69-421, Pt. 6(d) (3), 1969 INT. Rev. Bull. No. 32, at 36; E. R. Wagner Mfg. Co., 18 T.C. 657 (1952), acquiesced in result only, 1953-1 CuM. BULL. 6.

180 A curtailment would probably have an indirect rather than a direct effect upon carryovers-through plan disqualification. A curtailed plan would probably not be regarded as a terminated plan under the applicable regulations. See text accompanying notes $70 \& 159$ supra. 
vesting will be required with respect to any curtailed benefits. ${ }^{181}$ Second, a curtailed plan will be regarded as a partially terminated plan, ${ }^{182}$ so that continuing qualification on both a current and retroactive basis will be available only if the employer can establish to the satisfaction of the government (a) that the curtailment caused no prohibited discrimination ${ }^{183}$ and (b) that the curtailment was motivated by a business need. ${ }^{184}$ For purposes of these determinations, reference must be made to the criteria applicable to a full plan termination. ${ }^{185}$

To avoid the problem of curtailment, the acquiring corporation should seek prior government approval of any possibly troublesome amendments. ${ }^{186}$ The corporation should also realize, however, that certain plan modifications may be available only at an extremely high and unattractive price, payable only in part by the selling corporation through disallowed deductions, unless appropriate adjustments have been made in the price and terms of the acquisition.

\section{Merged Plan}

The acquiring corporation may wish to continue the seller's qualified deferred compensation plan, but on a merged rather than on a separate basis. For example, the buyer may wish to combine the seller's qualified plan with its already existing plan for salaried or nonunion personnel. There are, however, several potential problems with the merger approach. Curtailment may occur if the seller's plan is

181 INT. Rev. CoDe of 1954, §401(a) (7) ; Treas. Reg. \$1.401-6(b) (2) (1963) :

For purposes of this section, the term "termination" includes both a partial termination and a complete termination of a plan. . . . [W] hether or not a partial termination occurs when benefits or employer contributions are reduced, or the eligibility or vesting requirements under the plan are made less liberal, will be determined on the basis of all the facts and circumstances. However, if a partial termination of a qualified plan occurs, the provisions of section 401 (a) (7) and this section apply only to the part of the plan that is terminated.

182 Goodman, Permanency, supra note 86, at 50; Goodman, Termination, supra note 87, at 54; see Rev. Rul. 69-24, Sit. 6, 1969 INT. Rev. Bult. No. 4, at 13.

183 Rev. Rul. 69-421, Pt. 6(d) (3), 1969 Int. Rev. Bul.. No. 32, at 36; Rev. Rul. 69-24, Sit. 5, 1969 INT. Rev. Bul. No. 4, at 13; Rev. Rul. 69-25, §4, 1969 INT. REv. Bult. No. 4, at 15-16; Rev. Rul. 61-79, 1961-1 CuM. BuLL. 138; Duncan, supra note 7, at 1200-01; Goodman, Constructive Receipt under Pension and Profit-Sharing Plans, speech delivered at the Western Pension Conference, Los Angeles, Calif., Oct. 16,

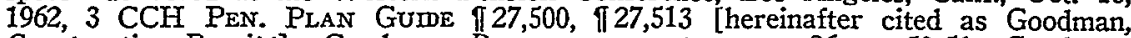
Constructive Receipt]; Goodman, Permanency, supra note 86, at 50-51; Goodman, Termination, supra note 87, at 54; Seligman, Jr., supra note 10, at 368; Taft, supra note 4 , at 476 .

184 Rev. Rul. 69-24, 1969 INT. Rev. Buld. No. 4, at 9, 10; Rev. Rul. 69-25, \$\$2.02, 4.05, 1969 INT. Rev. Bull. No. 4, at 14, 16; Duncan, supra note 7, at 1200-01; Goodman, Permanency, supra note 86, at 50; Goodman, Termination, supra note 87, at 54 ; Seligman, Jr., supra note 10 , at 368 ; Taft, supra note 4 , at 476 .

185 Rev. Rul. 69-24, 1969 INT. Rev. BuLl. No. 4, at 9, 10; Rev. Ru1. 69-25, § 4.05, 1969 INT. REv. BuLr. No. 4, at 16; see notes 78-120 supra \& accompanying text.

186 For a list of information that must be submitted to the government with a formal determination letter request see Rev. Proc. 69-4, § 4.04, 1969 INT. REv. BuLL. No. 1 , at 21 . 
amended to conform with the provisions of the buyer's current plan. ${ }^{187}$ Furthermore, even on a combined basis, the two plans may fail to meet the coverage requirements of the Code. ${ }^{188}$ Finally, several additional problems are peculiar to the merger route.

\section{Termination}

The buyer may find that merger results in plan termination, a result having a concomitant undesirable effect upon carryovers, any overfunding in the case of a pension plan, and the vesting formula in the case of a profit-sharing plan. Although the regulations provide that plan termination will not occur merely because an acquiring corporation consolidates or replaces the seller's qualified plan with a "comparable plan," 189 the scope of comparability is quite limited. A plan in category $X$ (pension plans) will be regarded as comparable to a plan in the same category, but will not be regarded as comparable to a plan in category $Y$ (profit-sharing, stock bonus, and employee annuity plans) ${ }^{100}$ Independent consideration of the question of comparability would appear to be available only in relation to the question of vesting. ${ }^{191}$ Thus, if the acquired corporation has a profit-sharing plan and the acquiring corporation has a pension plan, or vice versa, any attempt to combine the plans will generally result in termination for purposes of the carryover ${ }^{192}$ and vesting ${ }^{193}$ provisions of the Code.

If the combination is effected not by way of amendment, but rather by means of an actual plan termination followed by a transfer of funds to the acquiring corporation's plan, the additional questions of permanency and discrimination ${ }^{194}$ (of primary concern to the acquired

187 See notes $179-86$ supra \& accompanying text.

188 See notes 160-78 supra \& accompanying text.

189 Treas. Reg. $\$ 1.401-6(b)(1)$ (1963); Treas. Reg. $\$ 1.381(c)(11)-1(d)(2)$ (1961) ; see Rev. Rul, 67-213, 1967-2 Cum. BuLL. 149.

190 Treas. Reg. $\$ 1.381$ (c) (11)-1(d) (4) (1961); see Rev. Rul. 67-213, 1967-2 CuMr. BuLr. 149; I.T. 3660, 1944 CUM. BuLL. 136, where a qualified plan, designated as a profit-sharing plan, was found to be a pension plan for purposes of the deduction limitations under the Code.

191 The regulations under $\$ 401(\mathrm{a})(7)$ of the Code provide as follows:

[A] plan is not terminated merely because the employer sells or otherwise disposes of his trade or business if the acquiring employer continues the plan as a separate and distinct plan of its own, or consolidates or replaces that plan with a comparable plan. See paragraph (d) (4) of $\$ 1.381$ (c) (11) -1 for the definition of comparable plan. In addition, the Commissioner may determine that other plans are comparable for purposes of this section.

Treas. Reg. $\$ 1.401-6(b)$ (1) (1963).

192 Treas. Reg. $\$ \S 1.381$ (c) (11)-1(d) (2), (3), (4) (1961).

193 See note 67 supra; cf. Lurie, Plastic Contributions, supra note 11, at 1016. See also Seligman, Jr., supra note 10, at 369.

104 See Lurie, Plastic Contributions, supra note 11, at 1016; text accompanying notes 78-120 supra. At least one author has suggested that the same questions may arise in the case of a merger by way of amendment. Duncan, supra note 7, at 1201 n.13. 
corporation) will arise. There may also be a need to obtain the consent of all participating employees to the transfer of funds, ${ }^{\mathbf{1 9 5}}$ for the vesting provisions of the Code in effect give participants full control over plan assets upon an actual termination (except insofar as the plan calls for a deferred distribution of benefits).

No matter how the transfer is effected, the question of discrimination may also arise if pension plan funds are transferred to a profitsharing plan and, as a result of full vesting, the older employees come out ahead of the game. ${ }^{196}$ If the older employees are also highly paid, as is generally the case, the acquiring corporation may be forced to redistribute assets in accordance with the "termination rule," ${ }^{197}$ or otherwise, in order to eliminate the discrimination and preserve its plan qualification.

\section{Feeder Plan}

Various published rulings and the regulations ${ }^{198}$ generally provide that profit-sharing funds cannot be used to meet the costs under a qualified pension plan. Therefore, if the acquiring corporation has a pension plan and the selling corporation has a profit-sharing plan, combination will be impossible unless, contrary to the general rule, profit-sharing funds can be applied in reduction of the acquiring corporation's pension plan costs attributable to transferred employees. ${ }^{199}$ This will be possible only if the transferred employees consent to the transfer of their profit-sharing accounts, ${ }^{200}$ which will fully vest upon conveyance to a noncomparable plan.

\section{Gain}

The transfer of assets from one pension fund to another may result in gain, as the term is used in the government's ruling dealing with the transfer of assets to a pooled investment fund. ${ }^{201}$ The ad-

195 See Lurie, Pensions After Mergers, supra note 42, at 543; Robbins, supra note 4 , at 973-74.

196 See Cox, Corporate Acquisitions, supra note 4, at 443; Lurie, Pensions After Mergers, supra note 42, at 542; Lurie, Plastic Contributions, supra note 11, at 1016-18. 187 See text accompanying notes 87-94 supra.

198 Rev. Rul. 69-421, Pt. 2(q), 1969 INT. Rev. Butr. No. 32, at 17-18; Rev. Rul. 69-295, 1969 INT. REV. BuLt. No. 23, at 11, superseding PS No. 37, Oct. 7, 1944; Treas. Reg. \$1.401-1(b) (3) (1956); see Goodman, Tax-Qualified Profit-Sharing Plans, U. So. CaI. 1966 Tax InST. 269, 290.

199 For a discussion of the various uses to which profit-sharing funds may be put under a pension plan see Lurie, Pensions After Mergers, supra note 42 , at 541 ; Lurie, Plastic Contributions, supra note 11, at 1018.

200 Rev. Rul. 69-421, Pt. 2(q), 1969 INT. Rev. BuLl. No. 32, at 18; Rev. Rul. 69-295, 1969 INT. REv. BuLI. No. 23, at 11, superseding PS No. 37, Oct. 7, 1944; see Goodman, Tax-Qualified Profit-Sharing Plans, U. So. CAL. 1966 TAX INST. 269, $290-91$.

201 Rev. Rul. 57-165, 1957-1 Cum. Burc. 167. Compare Duncan, supra note 7, at 1203 , Robbins, supra note 4 , at 971 , \& Taft, supra note 4 , at 477 , with Cox, Corporate Acquisitions, supra note 4 , at 447 . 
ministrator of the acquiring corporation's pension plan will probably be required to carry transferred assets on its books at market value on the date of transfer, thereby forcing the acquiring corporation to take any overfunding or underfunding into account for purposes of determining its plan contributions and the deductibility thereof. ${ }^{202}$

\section{Mechanics}

In addition to problems of taxation, a variety of mechanical problems (some of which may involve questions of taxation) arise in connection with the merger of qualified deferred compensation plans. For example, benefits under the seller's qualified pension plan may be provided by a group deposit administration contract, while the buyer's plan may have only a separate investment fund. Or, the buyer's qualified profit-sharing plan may provide life insurance benefits, while the seller's plan may not. In some way, the plans of the buying and the selling corporations must be coordinated. ${ }^{203}$

A problem of fairness may also arise where full vesting is not required as a result of the merger of plans. In the case of a profitsharing plan, an amendment should perhaps provide that any forfeitures resulting from the termination of a transferred employee will enure to the benefit of other transferred employees; while in the case of a pension plan, an amendment should perhaps provide that all forfeitures resulting from the termination of transferred employees will be used to reduce the acquiring corporation's pension plan costs on account of nontransferred employees only in the event that the costs accrued on account of transferred employees have been fully paid to date. ${ }^{204}$ Such amendments may only be possible, however, if the acquired corporation is willing to pay for them in the form of a reduction in the acquisition price (or no increase therein on account of any overfunding).

\section{In What Manner Should the Seller's Plan Be Continued?-The Seller's Point of View}

\section{A. Continuing Qualification}

Of primary concern to the seller will be the questions of continuing qualification and retroactive disqualification in the event that the buyer decides to continue the seller's theretofore qualified deferred

202 The successor corporation would not, however, realize taxable income. Rev. Rul. 58-406, 1958-2 Cum. BuLc. 153. But cf. Robbins, supra note 4, at 975.

203 See Robbins, supra note 4, at 954-55; Seligman, Jr., supra note 10, at 374-78; and Taft, supra note 4 , at 477 , regarding the termination or transfer of a group annuity contract. See generally Cox, Corporate Acquisitions, supra note 4, at 439-41; Seligman, Jr., supra note 10, at 380-83.

204 See Cox, Corporate Acquisitions, supra note 4, at 441. 
compensation plan. Stated differently, the seller's basic concerns center around protection of any previously claimed deductions on account of plan contributions, ${ }^{205}$ and preservation of the benefits of a qualified plan for its key and continuing personnel.

\section{B. Constructive Receipt}

The selling corporation, however, will also be concerned with the problem of constructive receipt, a problem that will only indirectly concern the acquiring corporation. This problem will generally arise in the context of a merger of qualified plans.

Section 402 of the Code provides that participating employees will be taxed on those amounts allocable to them under a qualified deferred compensation plan only when such amounts are actually distributed or otherwise "made available" to them. ${ }^{206}$ Because the concept of availability has been equated with that of constructive receipt, ${ }^{207}$ an employee will be deemed to have received those funds allocable to him under a qualified plan when such funds are "unconditionally credited to or set apart for him and made subject to his withdrawal or other disposition." 208

If the acquiring corporation merely continues the qualified deferred compensation plan of the acquired corporation on an inactive or a separate basis, the interests of continuing employees will generally be made available to them only upon their actual termination of employment. In the case of a merger of plans, however, the answer is not so simple. Unless the transfer of funds is handled properly (from the point of view of the selling corporation), continuing employees will be deemed to have received at least their vested interests.

A number of safe approaches may be followed to avoid the problem of constructive receipt. ${ }^{209}$ If the transfer of funds is authorized by

205 Cf. Treas. Reg. $\$ 1.381$ (c) (11)-1(e) (1961) ; Rev. Rul. 58-406, 1958-2 CuMr. BULL. 153.

206 INT. Rev. Cone of 1954, $\$ 402$ (a) (1).

207 See Dillis C. Knapp, 41 B.T.A. 23 (1940); Cox, Corporate Acquisitions, supra note 4, at 445 n.102; Goodman, Constructive Receipt I27,500; Goodman, Reorganizations, supra note 21 , at 162 . A dissenting judge in the Knapp case criticized the failure to differentiate the concepts "constructive receipt" and "made available". 41 B.T.A. at 28-30.

208 Rev. Ru1. 55-423, 1955-1 Cum. Burl. 41; see Treas. Reg. \$1.451-2(a) (1957) (general definition of constructive receipt). See generally William B. Leavens, Jr., 44 T.C. 623 (1965) ; Estate of A. M. Berry, 44 B.T.A. 1254 (1941) ; Rev. Rul. 54-265, 1954-2 Cum. Bull. 239; Rev. Rul. 55-424, 1955-1 Cum. Bull. 42; Rev. Rul. 55-425, 1955-1 Cus. BuLI. 43; Rev. Rul. 57-260, 1957-1 Cum. Bunt. 164; Rev. Rul. 58-230, 1958-1 CuM. BuLr. 204; Rev. Rul. 60-292, 1960-2 CUM. BuLL. 153; letters to Federal Paper Board Co., Inc., Bogota, N.J., signed by Isidore Goodman, Chief, Pension Trust Branch, Internal Revenue Service, Jan. 13, 1958 and Apr. 23, 1959, 2 P-H PEN. \& Pro. Sharing III $11,957.1$ \& $11,957.2$.

209 However, a transfer of funds from a qualified profit-sharing plan to a qualified pension plan would under all circumstances result in taxable income to the extent of each transferred employee's vested interest (generally $100 \%$, due to the fact that a 
way of an amendment executed prior to any automatic plan termination and resultant vesting occasioned by the acquisition, there will be no constructive receipt. ${ }^{210}$ Even in the event of an actual plan termination, constructive receipt can be avoided in two ways: prior to actual termination, participants can agree to turn over to the buyer's qualified plan any funds that they receive, ${ }^{211}$ or, prior to the date on which they become eligible to receive any plan funds, participants may be given the option either to keep such funds or to turn them over to the administrator of the buyer's plan, with the understanding that, if they choose the former alternative, their rights under the buyer's plan will be limited (for example, they may lose the benefit of all past service for purposes of eligibility, vesting, and the determination of benefits).$^{212}$

Consent to the transfer of funds with a penalty may also be a safe haven if the seller's plan does not provide for an automatic distribution of assets in the event of full vesting occasioned by a corporate reorganization or a technical termination, the penalty being consent as a prerequisite to participation in the buyer's qualified plan. ${ }^{213}$ Finally, constructive receipt should not be a relevant factor when there is only a change in the funding vehicle. ${ }^{214}$

To the extent that constructive receipt is a potential problem, however, it would appear that the burden of prevention will be on the seller, who might wisely insist upon a preclosing amendment to its qualified plan or upon appropriate language in the purchase and sale agreement.

\section{Conclusion}

The issues raised by the seller's qualified deferred compensation plan in the context of a corporate acquisition are diverse and complex. Early and careful consideration should be given by both parties to the

profit-sharing plan and a pension plan will not generally be regarded as comparable under Treas. Reg. $\$ 1.401-6(b)$ (1) (1963)). If an employee were not deemed to be $100 \%$ vested by reason of the transfer of funds, query whether any amount over and above his vested interest could be transferred to the acquiring corporation's qualified pension plan. See Rev. Rul. 69-421, Pt. 2(q), 1969 INT. Rev. BuLl. No. 32, at 17-18; Rev. Rul. 69-295, 1969 INT. REv. BuLL. No. 23, at 11, superseding PS No. 37, Oct. 7, 1944.

210 See Rustigan, supra note 4, at 284.

211 Rev. Rul. 55-368, 1955-1 Cung. Burt. 40; see Goodman, Constructive Receipt II 27,511; Taft, supra note 4, at 484-85.

212 Rev. Rul. 55-317, 1955-1 Cum. Bulc. 329; see Robbins, supra note 4, at 973-74; Rustigan, supra note 4, at 284-85. The plan should be amended to incorporate these options. See William B. Leavens, Jr., 44 T.C. 623 (1965). For a discussion of the impact of consent without a penalty in the context of a plan termination giving rise to a distribution of funds see Lurie, Pensions After Mergers, supra note 42, at 543; Rustigan, supra note 4 , at 281 .

213 Rev. Rul. 67-213, 1967-2 CuM. Buld. 149; see Lurie, Pensions After Mergers, supra note 42, at 544; Lurie, Plastic Contributions, supra note 11, at 1018-19. \27,510.

214 Rev. Rul. 55-427, 1955-2 Cum. Bull. 27; see Goodman, Constructive Receipt 
questions of termination versus continuation, and the form thereof, thereby enabling the acquired corporation in particular to protect and defend its interests at the bargaining table, and enabling both the acquired and acquiring corporations to determine the role of the seller's qualified plan in the overall deal. The seller's plan can have a farreaching impact upon the price and terms of the acquisition, upon the extent and complexity of the preclosing procedures, and indeed upon whether there will be an acquisition. 